\title{
Radiological Assessment of Steam Generator Removal and Replacement: Update and Revision
}

Prepared by G. R. Hoenes, M. A. Mueller, W. D. McCormack

Pacific Northwest Laboratory

Operated by

Battelle Memorial Institute

Prepared for

U.S. Nuclear Regulatory

Commission 


\section{NOTICE}

This report was prepared as an account of work sponsored by an agency of the United States Government. Neither the United States Government nor any agency thereof, or any of their employees, makes any warranty, expressed or implied, or assumes any legal liability or responsibility for any third party's use, or the results of such use, of any information, apparatus product or process disclosed in this report, or represents that its use by such third party would not infringe privately owned rights.

\section{Available from}

GPO Sales Program

Division of Technical Information and Document Control

U. S. Nuclear Regulatory Commission Washington, D. C. 20555

Printed copy price: $\$ 4.50$

and

National Technical Information Service

Springfield, Virginia 22161 


\section{Radiological Assessment of Steam Generator Removal and Replacement: Update and Revision}

Manuscript Completed: November 1980

Date Published: December 1980

Prepared by

G. R. Hoenes, M. A. Mueller, W. D. McCormack

Pacific Northwest Laboratory

Richland, WA 99352

\section{Prepared for}

Division of Systems Integration

Office of Nuclear Reactor Regulation

U.S. Nuclear Regulatory Commission

Washington, D.C. 20555

NRC FIN No. B2322 



\section{ABSTRACT}

A previous analys is of the radiological impact of removing and replacing corroded steam generators has been updated based on experience gained during stearn generator repairs at Surry Unit 2. Some estimates of occupational doses involved in the operation have been revised but are not significantly different from the earlier estimates. Estimates of occupational doses and radioactive effluents for new tasks have been added. Health physics concerns that arose at Surry included the number of persons involved in the operation, the training of workers, the handling of quantitites. of low-level waste, and the application of the ALARA principle. A review of these problem areas may help in the planning of other similar operations. A variety of processes could be used to decontaminate steam generators. Research is needed to assess these techniques and their associated occupational doses and waste volumes. Contaminated steam generators can be stored or disposed of after removal without significant radiological problems. Onsite storage and intact shipment have the least impact. In-placing retubing, an alternative to steam generator removal, results in occupational doses and effluents similar to those from removal, but prior decontamination of the channel head is needed. The retubing option should be assessed further. 
, 
SUMMARY

The accumulation of corrosion products has made frequent maintenance and inspection of steam generators necessary at several power reactors to ensure their continued safe operation. The maintenance and inspection work has led to increasing radiation exposures to the workers who perform these tasks. Several power reactor owners have therefore considered replacing the existing steam generators with new ones. This procedure involves a significant amount of occupational dose, but can save even more by reducing the radiation field and the need for frequent maintenance and inspection. It will also lead to more economic plant operation with fewer power output interruptions.

The removal and replacement of steam generators is a unique occurrence during the lifetime of an operating power reactor. Some of the largest and some of the most radioactive components of the primary system must be handled during these operations. This study, an analysis of the radiological impact of steam generator repair operations, is an update and revision of a previous study on the same subject.

Some of our previous estimates of the occupational doses associated with removing and replacing a steam generator have been revised based on experience gained during steam generator repairs at Surry Unit 2 and on other new information related to radiation exposure rates and on-the-job time estimates. However, the revised dose estimates in this report are not significantiy different from those presented previously. Some estimates of accupational dose and effluents for new tasks have been added based on steam generator repair plans for Turkey Point and Palisades.

The waste volumes and occupational doses associated with steam generator decontamination are not well known; some research and demonstration of steam generator decontamination are needed to determine which techniques are best and what the consequences of decontamination might be. 
The storage or disposal of contaminated steam generators following their removal does not present any significant radiological problems. Onsite storage and intact shipment of the steam generators are the options with the least impacts. If the steam generators must be cut up before shipment, it is beneficial from a dose and effluent standpoint to allow a period for radioactive decay.

An alternative to removal and replacement is retubing the steam generator in place. An analysis of this option shows that the resulting occupational doses and effluents are similar to those involved in removal and replacement. In addition, the channel head of the steam generator must be decontaminated before retubing can begin. The number of unknowns currently associated with steam generator decontamination do not make this a simple task. Before a retubing can be done in an operating reactor, equipinent and procedures must be thoroughly tested.

Experience gained at Surry Unit 2 highlighted the health physics concerns that arise during steam generator removal and replacement. The next such operations will have the advantage of using experienced personnel who have a more thorough knowledge of potential health physics problems. The following areas are essential to good health physics practices during steam generator repair operations: in-depth planning with health physics participation; training specifically geared to steam generator repair operations, with special attention given to individuals who have not previously worked in radiation zones; dose tracking techniques to define hign-exposure-rate locations and high-dose tasks so that engineering approaches can be revised when necessary; and worker briefing sessions to clarify the work to be done and to reinforce safety awareness. 


\section{CONTENTS}

ABSTRACT • . . . . . . . . . . . . . . . . . . . . . . .

SUMMARY

INTRODUCTION

CONCLUSIONS AND RECOMMENDATIONS

CHARACTERIZATION OF A GENERIC PLANT

SOURCES OF RADIATION EXPOSURE IN A STEAM GENERATOR

EXPOSURE RATES IN CONTAINMENT BUILDINGS AND STEAM GENERATORS

ASSESSMENT OF OCCUPATIONAL DOSES $\quad \cdot \quad \cdot \quad \cdot \quad \cdot \quad \cdot \quad \cdot \quad \cdot$

DISCUSSION OF ESTIMATED GENERIC DOSES $\quad \cdot \quad \cdot \quad \cdot \quad \cdot \quad \cdot \quad 19$

VARIABLES THAT AFFECT DOSES AT INDIVIDUAL PLANTS • $\quad$ • $\quad 20$

COMPARISON OF GENERIC DOSES WITH UTILITIES' DOSE ESTIMATES • 22

ESTIMATED RELEASES OF RADIONUCLIDES TO THE ENVIRONMENT AND

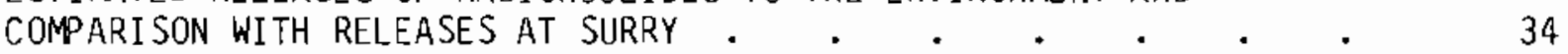

AIRBORNE RELEASES . . . . . . . . . . . . 34

WATERBORNE RELEASES . . . . . . . . . . . 36

SOLIO WASTES $\quad . \quad$. . . . . . . . . . . . . 37

OTHER SAFETY CONCERNS . . . . . . . . . . . . . . . . . 43

LEARNING FROM EXPERIENCE: STEAM GENERATOR REPAIR

MANAGING LARGE NUMBERS OF WORKERS . . . . . . . 44

TRAINING WORKERS FOR THE JOB

BRIEFING WORKERS . . . . . . . . . . . 46

BUILDING CONTAMINATION CONTROL STRUCTURES $\quad . \quad . \quad . \quad . \quad 46$

HANDLING LOW-LEVEL WASTE . . . . . . . . . . 46

LIMITING DOSE TO OBSERVERS $\quad . \quad . \quad . \quad . \quad . \quad . \quad \cdot \quad 47$ 


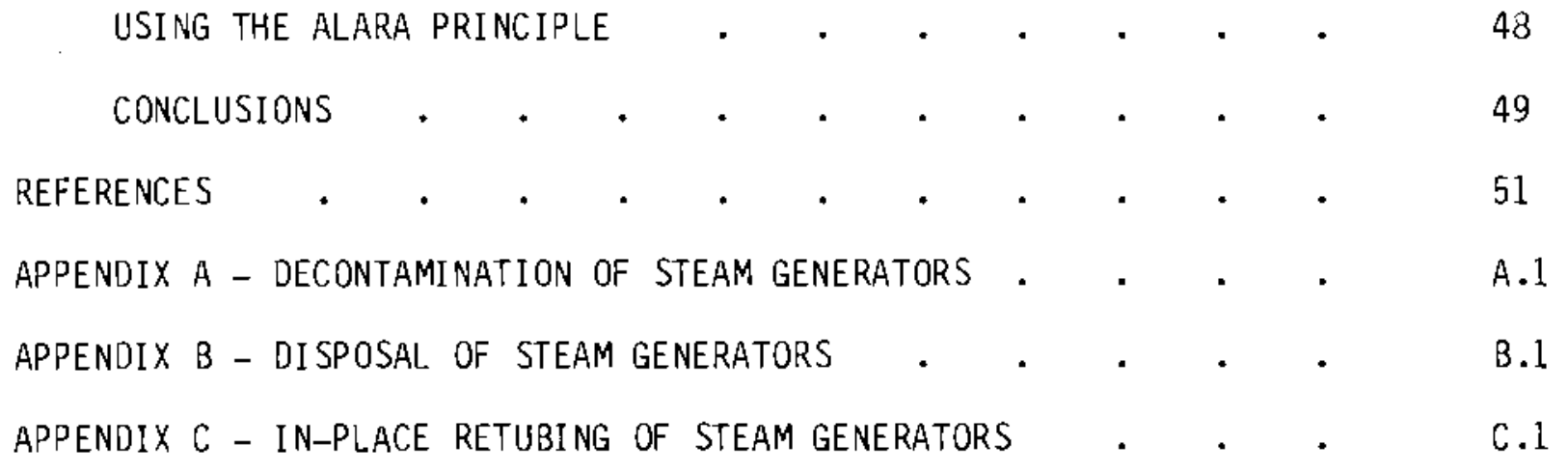




\section{FIGURES}

1 Cutaway View of Stean Generator . . . . . . . 10

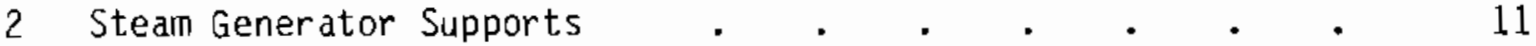

3 Source Locations in Containment Building at 13-m Elevation . 14

4 Source Locations in Containment Building at 19-m Elevation . 14

5 Source Locations in Containment Building at 23-m Elevation . 15

6 Source Locations in Containment Building at Operating Floor and Above ( $\geq 28-m$ Elevation) $. \quad . \quad . \quad . \quad . \quad 15$

7 Source Locations in Stean Generator . . . . . . 17

8 Cut Locations on Reactor Coolant Piping $\quad . \quad$. $\quad . \quad$. $\quad 29$

9 External View of Cut Locations on Channel Head . . . 30

10 Cross-Sectional View of Channel Head Cut Line . . . . 31 


\section{TABLES}

1 Steam Generator Design Data . . . . . . . . 12

2 Sources of Radiation Fields in Steam Generators as a

Function of Effective Full-.Power Days . . . . . . . 12

3 Exposure Rates in Containment Buildings by Location . . 13

4 Exposure Rates in Steam Generators by Location . . . 16

5 Post-Shutdown Preparation . . . . . . . . . . 24

6 Removal of Lower Steam Generator Assembly . . . . . $\quad 25$

7 Installation of Replacement Lower Assembly . . . . . 27

8 Dose Reductions Possible Through Man-Rem-Saving Techniques * 32

9 Comparison of Generic and Utilities' Occupational Dose

Estimates . $. \quad . \quad . \quad . \quad . \quad . \quad . \quad . \quad . \quad 33$

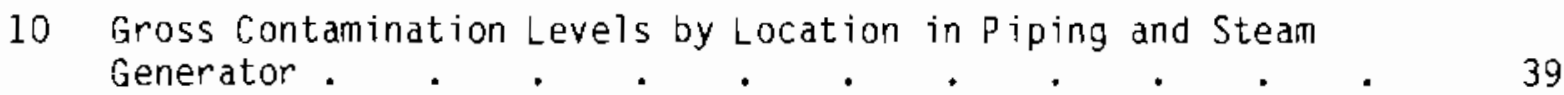

11 Contamination Levels by Radionuclides on Steam Generator Channel Head . . . . . . . . . . . . 39

12 Radionuclide Concentrations in Reactor Coolant. . . . 40

13 Decontamination Factors Used to Calculate Radionuclide

Releases in Liquids . . . . . . . . . . 40

14 Estimated Radionuclide Releases Due to Discharge of Reactor Coolant water . . . . . . . . . . 41

15 Radionuclide Concentrations in Laundry waste Water . . 42

16 Estimated Radionuclide Releases Due to Discharge of Laundry Waste Water . $\quad . \quad$. $\quad . \quad$. . . .

A.1 Occupational Dose Estimates for Decontamination of a Stean Generator . . . . . . . . . A.8

A.2 Occupational Dose Estimates for Tasks During a Stean Generator Decontamination . . . . . . . A.10 
B.1 Exposure, Time, and Man-Rem Estimates for Various Operations During Disposal of Steam Generators . . . . .

B.2 Comparison of Man-rem Estimates for Steam Generator Disposal Alternatives $. \quad . \quad . \quad . \quad . \quad . \quad . \quad . \quad$.

B.3 Comparison of Estimated Occupational Dose for Steam Generator Disposal Alternatives . . . . . . . . .

B.4 Comparison of Airborne Effluents for Steam Generator Disposal Alternatives. . . . . . . . . .

C.1 Steam Generator In-Place Retubing . • • . . . . . C.8 

RADIOLOGICAL ASSESSMENT OF

STEAM GENERATOR REMOVAL AND REPLACEMENT:

UPDATE AND REVISION

INTROOUCTION

Corrosion problems in steam generators at several nuclear power plants have led to the need for periodic inspection and maintenance (plugging) of the steam generator tubes to ensure continued safe operation. This situation has also resulted in lower power output from the affected plants because of inspection and maintenance outages and because of lower heat transfer efficiency resulting from the plugging. Efforts to inspect and repair steam generators to maintain appropriate safety margins have resulted in such severe economic and occupational dose problems that some utilities have chosen to remove an entire steam generator or a portion of it and replace it with a new one. The removal, replacement, and refurbishment of steam generators presents a complex radiological problem.

The evaluation of alternatives for steam generator maintenance must involve consideration of all related costs. Costs of considerable importance are 1) the occupational radiation dose and 2) the radioactive effluents (i.e., gaseous, liquid, and solid wastes) resulting from the operation. While long-term savings may result from the replacement of steam generators, the potentialiy high occupational radiation dose and the quantity of radioactive effluents involved must be controlled during maintenance activities.

In 1978, the Nuclear Regulatory Commission (NRC) funded a study by the Pac if ic Northwest Laboratory (PNL) that resulted in the publication of NUREG/CR-0199, Radiological Assessment of Steam Generator Removal and Replacement. (1) In 1979, steam generator removal and replacement operations were conducted by Virginia Electric and Power Company (VEPCO) at the ir Surry power station, Unit number $2,{ }^{(2-7)}$ and since then several utilities have reached various stages in their plans to replace corroded, contaminated, and 
increasingly inefficient steam generators. It was the opinion of PNL and NRC, following the steam generator replacement operations at Surry Unit 2, that changes in the original report were necessary even though the general approach and conclusions remain valid. In this report, therefore, we have considered what was learned during the Surry Unit? operations, addressed changes that have been made in plans for future steam generator repair operations, and included information gained on related subjects since the first report.

The analysis provided here includes a detailed estimate of the occupational dose received during the removal of contaminated steam generator assemblies from a generic power reactor and their replacement with new assemblies. The radiation exposure rates used to arrive at the occupational dose estimate were based on measurements made at operating power reactors. (8) For this analysis, the nigh end of the exposure rate ranges found at various locations in the reactor containment building was chosen to assure a conservative approach in estinating the radiation dose to workers. Where possible, comparisons with utility estimates are made and tasks that result in high doses are identified. A variety of engineering approaches to the steam generator removal, replacement, and repair operations is possible. Most of them are similar to the procedures followed by Surry unit 2, with alterations based on plant-specific features. Consideration of the alternative approaches is included in this report. The amounts of airborne, waterborne, and solid radioactive waste resulting from steam generator removal and replacement are also estimated based on the characteristics given for a generic power reactor, and comparisons with the releases at Surry are given.

The stearn generator removal and replacement operation at Surry was the first of its kind, and a review of the health pnysics concerns that arose during the operation may be helpful in the planning of other similar operations. The topics covered here include the numbers of workers and observers present, the preparation of workers for their jobs, the handling of quantitites of lowlevel waste, and the application of the principle that occupational exposures should be kept as low as is reasonably achievable. Suggestions for minimizing problems in these areas are given. 
In addition, three appendices provide information relevant to steam generator removal and replacement. In Appendix $A$, the impact of decontaminating steam generators in place prior to performing any maintenance operations is discussed. Appendix $B$ is a discussion of disposal alternatives for steam generators once they have been removed. Appendix $C$ deals with an alternative to removal and replacement suggested by a vendor of nuclear steam supply systems: in-place retuoing of the steam generators.

The analyses in this report cover U-tube stear generators in particular, but the technique may be adapted to other types of steam generators and other reactor system components. 


\section{CONCLUSIONS AND RECOMMENDATIONS}

The totai occupational doses estimated for each phase of maintenance activity on a single generic steam generator are given below:

- Post-shutdown preparation............270 to 310 man-rem

- Removal of steam generator...........290 to 420 man-rem

- Installation of new steam generator.....2 240 to 830 man-rem

These conservative, generic estimates are consisten-ly nigher than those made by three utilities proposing to do steam generator removal and replacement operations because we have attempted to estimate an upper bound for the occupational dose from these operations.

High-dose activities are generally those involving work in the vicinity of reactor coolant piping or the channel nead of the steam generator. Specific activities that tend to lead to high occupational dose are cutting and removing reactor coolant piping, cutting the steam generator at the channel head, removing steam generator supports, and welding reactor coolant piping or the channel head.

We estimated the amounts of liquid, solid and airborne effluents associated with the removal and replacement of a steam gererator. Total liquid releases to the environs amount to a maximuin of about $190 \mathrm{C} i$ of tritium and $0.23 \mathrm{Ci}$ of other radionuclides. Approximately $760 \mathrm{~m}^{3}$ of low-level solid waste must be disposed of following steam generator removal and replacement. This total may be substantially increased if large amounts of disposable clotning are used, the reactor coolant piping or channel head is decontaminated, or a hole is cut in the containment building for easier removal of the steam generator. Airborne releases are generated primarily ty cutting operations. We estimate that between $7.0 \times 10^{-5}$ and $7.5 \times 10^{-5} \mathrm{C}$ i of particulate material will be released per steam generator. Airborne releases can be kept low by using contamination control envelopes with hign-efficiency particulate air (HEPA) filters and by exhausting all air through the containment building's ventilation system.

A decontamination process is one means of reducing radiation exposure rates so that work may be done with less occupational dose. Decontamination 
of a steam generator in place is a difficult procedure. Several types of processes, which can be grouped into three categories (chemical, mechanical, and water chemistry modification), can used to decontaminate a steam generator. No matter which method is chosen, detailed planning and extensive training of crews is necessary to ensure an efficient and effective decontamination operation. Before any method can be widely used for steam generator decontamination, its effectiveness on the corrosion films and deposits found in pressurized water reactors must be demonstrated.

The occupational dose received and the amount of radioactive waste generated during a steam generator decontamination vary with the type of process used. 0ccupational doses for steam generator decontamination are estimated to be in the range of 5 to 200 man-rem. The volume of liquid waste is estimated to be from 11,300 to 568,0001 depending on the process employed.

The largest piece of waste handled during the removal and replacement operation is the steam generator itself. A steam generator weighing about 310 megagrams contains 400 to $1000 \mathrm{Ci}$ of radioactive material. Several methods of handing the used steam generators are possible. The following list shows the occupational dose associated with each alternative.

\begin{tabular}{lc}
- Alternative & Dose, man-rem \\
\hline - Long-term onsite storage & $60-230$ \\
- Interim onsite storage & $270-580$ \\
- Immediate cut-up and shipment & \\
- to burial site & $2.4-5.0$
\end{tabular}

An alternative to removing and replacing steam generators is to retube the generator in place. The total occupational dose we estimated for the retubing operation on a single steam generator is $\sim 2300$ man-rem. Liquid releases from this operation, primarily from reactor coolant and laundry waste water, would be similar to those from stearn generator removal and repiacement. Approximately $1000 \mathrm{~m}^{3}$ of low-level solid waste must be disposed of per steam generator. 
In addition, the tubes that would de removed from a steam generator would be packaged in three containers with a volume of 8.5 to $15 \mathrm{~m}^{3}$ each. Tube stubs would be packaged in about 20 drums with a total volume of about $4 \mathrm{~m}^{3}$. Airborne releases would result primarily from cutting the cnannel head and the tubes and piping associated with the steam generator. About $7.3 \times 10^{-4} \mathrm{C} i$ of radioactive material would be released to the environs per steam generator during retubing operations.

Retubing steam generators may be a viable alternative to removal and replacement, but significantly more information needs to be gathered. of primary concern are the effectiveness of channel head/tubesheet decontamination, the amount of waste and the occupational dose generated during the decontamination, the operation and maintenance of the Re macione, and the need for extensive training of individuals and crews to perform the retubing. An application of retubing is necessary to verify that it is economically feasible without causing excessive occupational dose or creating large amounts of radioactive effluents.

Al1 of the estimates in this report are for a generic case. Occupational dose and radiological effluent estimates vary widely from plant to plant because engineering approaches to the same problem may differ, as may the radiation exposure rate in any given area. In this report, we have attempted to estimate an upper bound for the occupational doses that might be expected during steam generator repair operations. With prudent engineering controls and administrative techniques, the occupational doses and radiological effluents actually encountered will probably be less than those reported in this document.

Following is a list of what we believe to be the most important healthphysics-related recommendations resulting from this study and from the steam generator removal and replacement operations at Surry Unit 2 .

1. Planning is an extremely important aspect of an outage for major maintenance work such as the replacement of a steam generator. It is important to include health physicists as part of the planning team so that they can participate in the design of operations and ensure that 
occupational doses are maintained as low as is reasonably achievable. The health physics staff can then plan properly for the number of workers expected and anticioate the anount of radioactive waste that will need to be handled.

2. Training should be geared to the specifics of stean generator removal and replacement operations. Special attention should be given to workers who are not familiar with work in radiation zones, and health physics training should be continually reinforced throughout the operation. Any questions tnat arise should be clearly and concisely answered to the satisfaction of the worker. Mockups should be used whenever possible so that workers can practice the performance of tasks.

3. Briefings to instruct workers on what they are to do for eacn specific task and to reinforce their awareness of the safety and radiation protection measures that must be observed can result in jobs being carried out in less time and with a lower risk to workers. Briefings following the completion of tasks will help in the formulation of plans for similar work or other work in the same location.

4. Tours of work areas to determine what an area looks like as opposed to what drawings show can help in the planning of tasks.

5. Exposure tracking techniques can be useful in monitoring the amount of occupational dose incurred during the performance of the various steam generator removal and replacement tasks. Through proper application of these techniques, future planning for many types of operations will be enhanced.

6. Whenever possible, the water level on tne secondary side of the steam generator should be maintained in order to reduce exposure rates. 


\section{CHARACTERIZATION OF A GENERIC PLANT}

The generic steam generator shown in $F$ igures 1 and $2^{(a)}$ is a vertical shell and U-tube evaporator with integral moisture-separating equipment. The reactor coolant flows through the inverted u-tubes, entering and leaving through the inlet and outlet pipes located in the hemispherical bottom head of the steam generator. The head is divided into inlet, and outlet chambers by a vertical partition plate extending from the head to the tubesheet. Manways are provided for access to both sides of the divided head. Steam is generated on the secondary side of the tubesheet and flows upward through the moisture separators to the outlet nozzle at the top of the vessel.

The steam generator is constructed primarily of carbon steel. The heat transfer tubes and the partition plate are Inconel, ${ }^{\circledR}$ and the interior surfaces of the reactor coolant channel head and nozzles are clad with austenitic stainless steel. The primary side of the tubesheet is weld clad with Inconel. Table 1 provides some data on steam generator design ${ }^{(8-10)}$ pertinent to this study.

\section{SOURCES OF RADIATION EXPOSURE IN A STEAM GENERATOR}

The radiation field in and around a steam generator and other primary system components is created by corrosion products that become activated in the reactor core. Following activation, these corrosion products are solubil. ized or eroded into the reactor coolant and deposited on out-of-core surfaces. The radionuclides form a film on reactor components and systems, such as steam generators.

Experimentation has verified that exposure rates in steam generators are caused primarily by the activated corrosion products ${ }^{58} \mathrm{Co}$ and ${ }^{60} \mathrm{Co},(11-14)$ and has shown that ${ }^{60} \mathrm{Co}_{0}$ increasingly dominates the radiation field after the plant has been in operation for a few years. $(11,13)$ Measurements at a

(a) The figures and tables referred to in text are located at the back of each text section throughout this report.

(B) Registered trademark of Huntington Alloys. 
reactor site indicate that the most notable difference between the end of cycle 1 ( $E O C 1$ ) and the end of cycle 2 ( $E O C 2$ ) is the increase in the out-of-core ${ }^{60} \mathrm{Co}$ activities. ${ }^{(11)}$ The radiation exposure rates on the steam generator tubesheets remain virtually unchanged between $E O C 1$ and EOC 2, but the ${ }^{60} \mathrm{Co}$ contribution to the exposure rate increases significantly, as shown in Table 2. (11) By EOC 3,70\% of the exposure rate is attributed solely to ${ }^{60} \mathrm{Co} .(11)$

Measurements performed by Westinghouse to determine the composition of the crud on the steam generator manway at a plant that has been in operation for 5 years indicate that ${ }^{58} \mathrm{Co}$ and ${ }^{60} \mathrm{Co}_{0}$ make up from $40 \%$ to $64 \%$ of the total deposited activity. (13) This Co activity accounts for approximately 87 of the total dose rate at a distance of $1 \mathrm{~m}$ from the steam generator. (13) Westinghouse has found similar results at other power reactors. (13)

\section{EXPOSURE RATES IN CONTAINMENT BUILDINGS AND STEAM GENERATORS}

Radiation exposure rates have been measured during shutdown at several pressurized water reactors (PWRS) ${ }^{(a)}$ that had been operating from 3 to 6 years. ${ }^{(8)}$ The exposure rates found did not vary greatly from site to site. ${ }^{(8)}$ Representative radiation exposure rates measured in containment buildings are presented in Table 3 , with the locations of the measurements shown in Figures 3 through 6 . Measured radiation exposure rates for a "typical" steam generator are listed in Table 4, with the locations shown in Figure 7.

(a) Measurements were taken at the following reactors: Carolina Power and Light Co. - H. B. Robinson Unit No. 2 Florida Power and Light Co. - Turkey Point Unit Nos. 3 and 4 Rochester Gas and Electric Co. - R. E. Ginna Virginia Electric and Power Co. - Surry Unit Nos. 1 and 2 


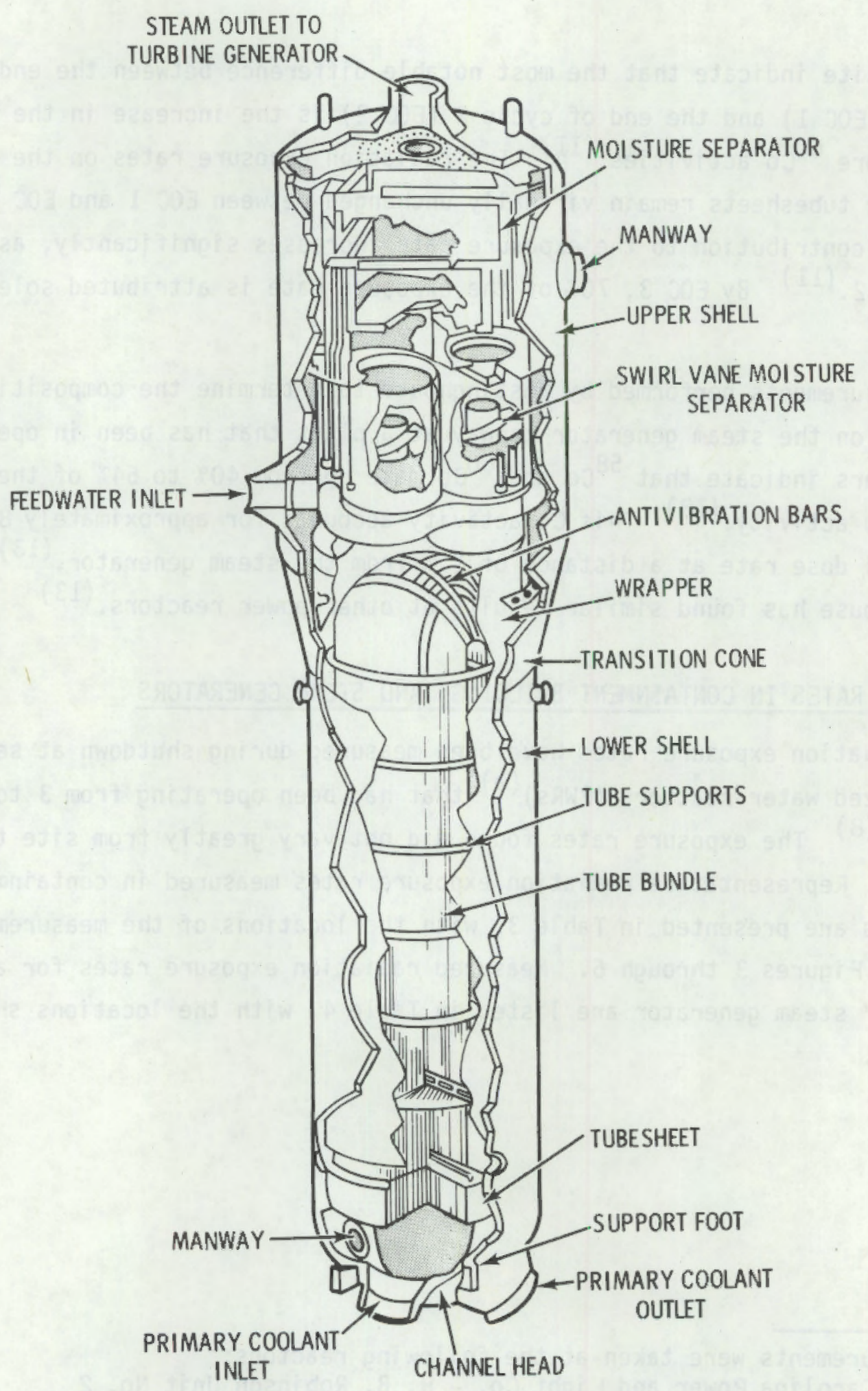

FIGURE 1. Cutaway View of Steam Generator (U-Tube Type) 


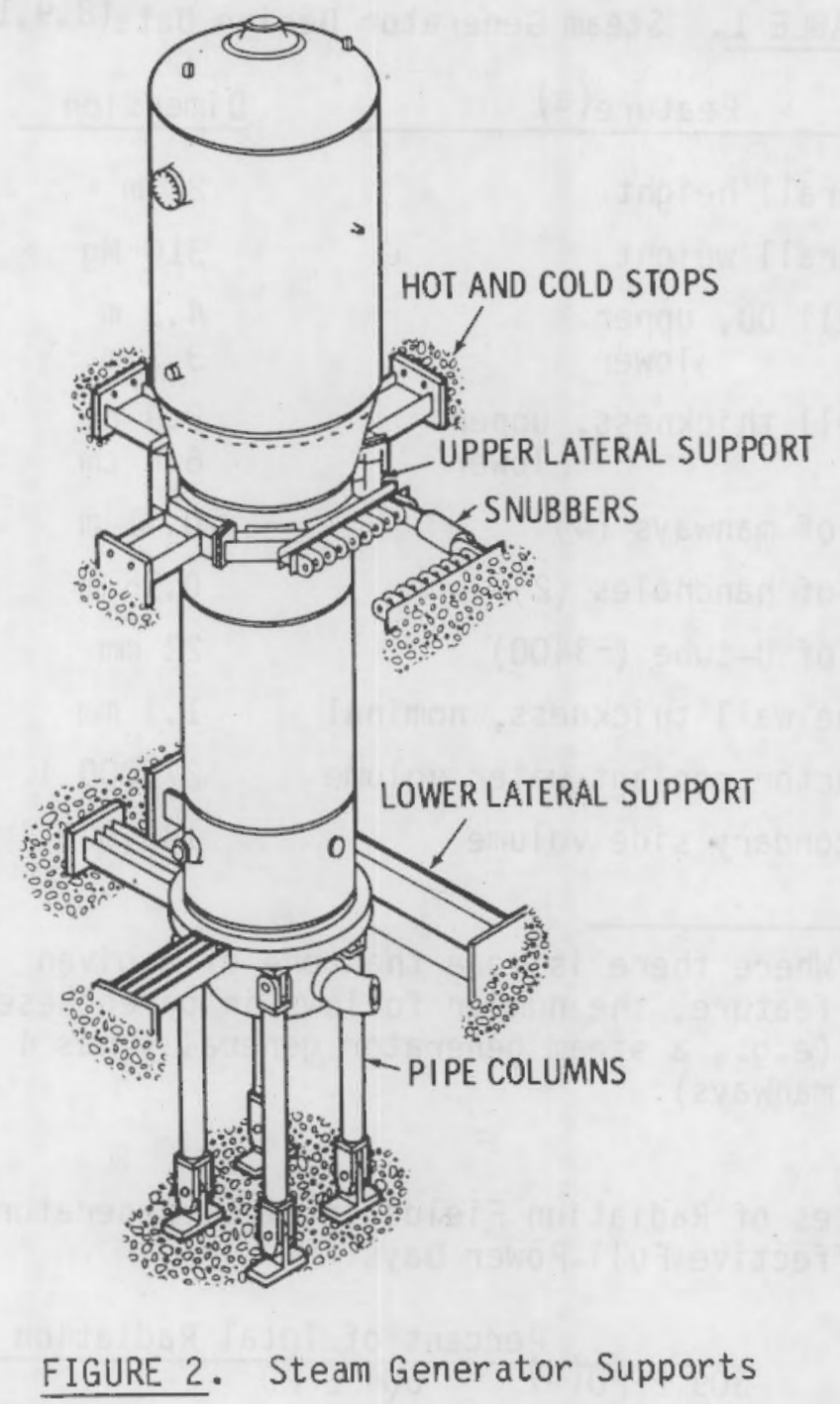


TABLE 1. Steam Generator Design Data $(8,9,10)$

\begin{tabular}{lll}
\multicolumn{1}{c}{ Feature (a) } & & Dimension \\
\cline { 1 - 1 } Overall height & $21 \mathrm{~m}$ \\
Overall weight & $310 \mathrm{Mg}$ \\
Shell OD, upper & $4.3 \mathrm{~m}$ \\
lower & $3.3 \mathrm{~m}$ \\
Shell thickness, upper & & $8.9 \mathrm{~cm}$ \\
& $6.6 \mathrm{~cm}$ \\
ID of manways (4) & $0.41 \mathrm{~m}$ \\
ID of handholes (2) & $0.15 \mathrm{~m}$ \\
OD of U-tube ( 3400) & $22 \mathrm{~mm}$ \\
Tube wall thickness, nominal & $1.3 \mathrm{~mm}$ \\
Reactor coolant water volume & 27,0001 \\
Secondary side volume & 130,000 I
\end{tabular}

(a) Where there is more than one of a given feature, the number follows in parentheses (e.g., a steam generator generally has 4 manways).

TABLE 2. Sources of Radiation Fields in Steam Generators as a Function of Effective Ful1-Power Days(11)

\begin{tabular}{|c|c|c|c|c|}
\hline Radionuclide & $\begin{array}{l}\text { POg EFPD }(d) \\
\text { EOC } 1 \\
\end{array}$ & $\begin{array}{l}\text { nt of Tot } \\
604 \text { EFPD } \\
\text { EOC } 2 \\
\end{array}$ & $\begin{array}{l}\text { Iadiation } \\
752 \text { EFPD }\end{array}$ & $\begin{array}{l}\text { Id } \\
916 \text { EFPD } \\
\text { EOC } 3 \\
\end{array}$ \\
\hline${ }^{51} \mathrm{Cr}$ & 1 & 1 & 0.2 & -- \\
\hline${ }^{54} \mathrm{Mn}$ & 3 & 2 & 1 & 0.8 \\
\hline${ }^{58} \mathrm{Co}$ & 65 & 46 & 28 & 29 \\
\hline${ }^{59} \mathrm{Fe}$ & 3 & 1 & - & -- \\
\hline${ }^{60} \mathrm{Co}$ & 26 & 49 & 70 & 70 \\
\hline${ }^{95} \mathrm{Zr}$ & 2 & 1 & 0.6 & 0.2 \\
\hline
\end{tabular}

(a) Effective full-power days. 
TABLE 3. Exposure Rates in Containment Buildings by Location( 8 )

\begin{tabular}{|c|c|c|}
\hline $\begin{array}{c}\text { Measurement } \\
\text { Point (a) } \\
\end{array}$ & $\begin{array}{r}\text { Exposure } \\
\text { Rate, R/h }\end{array}$ & Location(b) \\
\hline $1 \mathrm{~A}-01$ & $12-30$ & Reactor coolant pump bowl (contact) \\
\hline $1 \mathrm{~A}-02$ & $0.5-0.6$ & RCS piping, cold leg (contact) \\
\hline $1 A-03$ & $0.05-0.4$ & Steam generators (general area) \\
\hline $1 \mathrm{~A}-04$ & $0.001-0.012$ & Emergency personnel hatch \\
\hline $1 A-05$ & $0.01-0.6$ & Floor drains (contact) \\
\hline $1 \mathrm{~A}-06$ & $0.01-0.15$ & General area (typical) \\
\hline $1 \mathrm{~A}-07$ & $0.025-0.1$ & RCS pumps (general area) \\
\hline $1 A-08$ & $0.35-0.8$ & SG loop to RCS pump (typical) \\
\hline $1 A-09$ & $18-22$ & SG at manway (typical) \\
\hline $1 \mathrm{~A}-10$ & $0.5-0.7$ & $S G$ at $0.9 \mathrm{~m}$ (typical) \\
\hline $1 A-11$ & $<0.3$ & SG at $1.5 \mathrm{~m}$ (typical) \\
\hline $1 \mathrm{~A}-12$ & $\leq 0.2$ & SG at $1.8 \mathrm{~m}$ (typical) \\
\hline $1 \mathrm{~A}-13$ & $\overline{0} .05-0.15$ & General area (typical) \\
\hline $1 \mathrm{~A}-14$ & $\leq 0.04$ & General area \\
\hline $1 \mathrm{~A}-15$ & $\overline{0} .15-3.0$ & Piping (systematic) \\
\hline $1 \mathrm{~A}-16$ & $<0.5$ & Sump, reactor building \\
\hline $1 \mathrm{~A}-17$ & $<0.001$ & Personnel hatch (outside CV) \\
\hline $2 A-01$ & $\overline{<0} 0.025$ & General area (typical) \\
\hline $2 \mathrm{~A}-02$ & $\geq 0.2$ & Pressurizer (contact) \\
\hline $2 A-03$ & $\leq 0.2$ & Reactor coolant pump (contact) \\
\hline $2 A-04$ & $\overline{0} .1-0.9$ & General area (typical) \\
\hline $2 A-05$ & $0.01-0.2$ & Steam generator area \\
\hline $3 A-01$ & $0.005-0.02$ & General area (typical) \\
\hline $3 A-02$ & $0.01-0.2$ & Steam generator area \\
\hline $4 A-01$ & $0.1-1.0$ & Reactor cavity (inside edge) \\
\hline $4 A-02$ & $\geq 0.2$ & SG (general area) \\
\hline $4 A-03$ & $\overline{0} .005-0.05$ & General area \\
\hline $4 A-04$ & $0.005-0.05$ & Equipment hatch \\
\hline $4 A-05$ & $\geq 0.2$ & Above RV on cooling duct (general area) \\
\hline $4 A-06$ & $\geq 0.6$ & RCS piping \\
\hline
\end{tabular}

(a) See Figures 3-6 for locations of measurement points. 1A designates 13-m elevation (Figure 3 ); $2 \mathrm{~A}$ designates $19-m$ elevation (Figure 4); $3 \mathrm{~A}$ designates $23-\mathrm{m}$ elevation (Figure 5 ); $4 \mathrm{~A}$ designates elevations $>28 \mathrm{~m}$ (Figure 6 ).

(b) $\overline{\mathrm{R} C S}=$ reactor coolant system; $S G=$ steam generator; $\mathrm{CV}=$ containment vessel; $\mathrm{RV}=$ reactor vesse $\mathrm{l}$. 

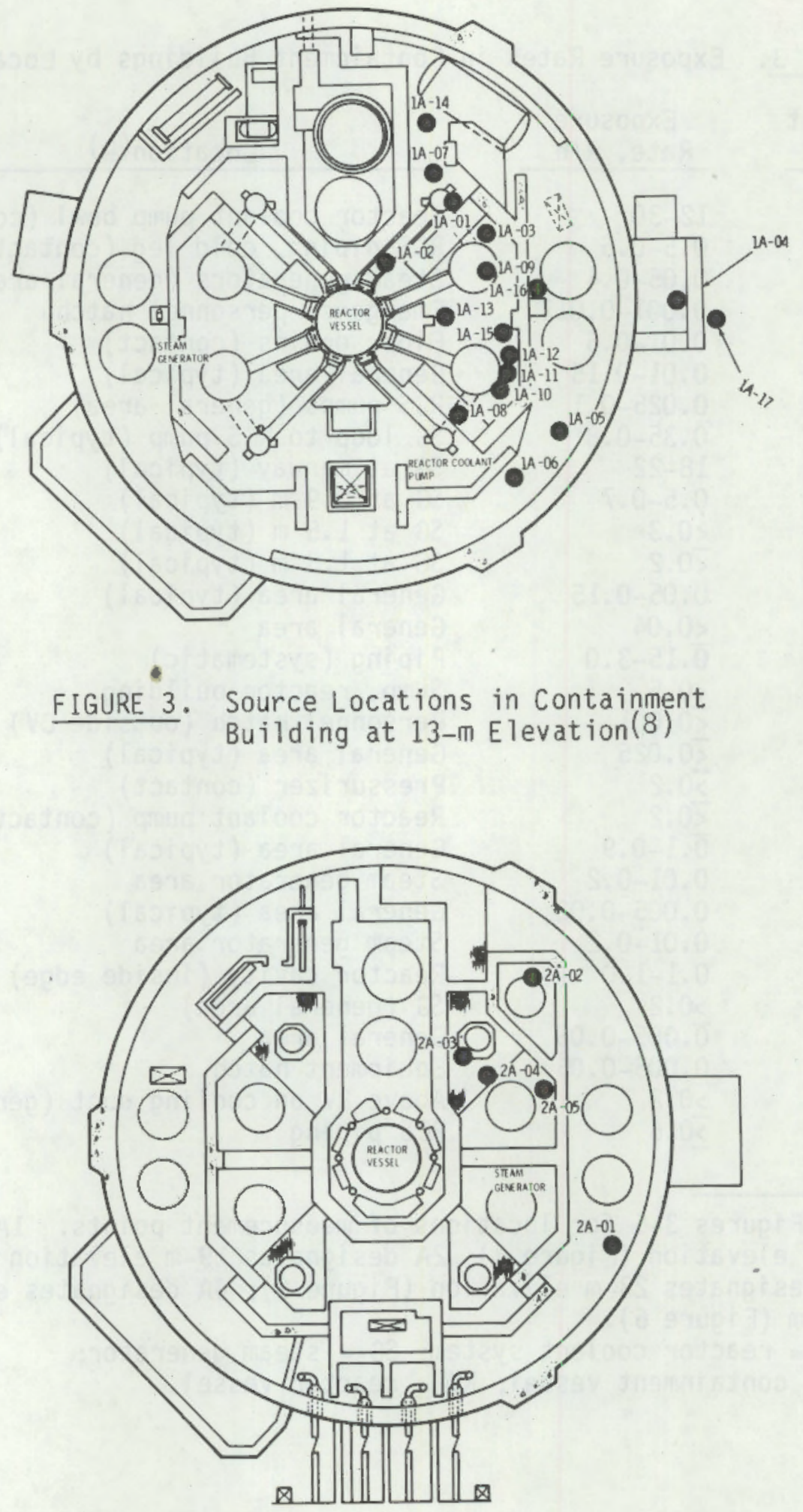

FIGURE 4. Source Locations in Containment Building at 19-m Elevation(8) 


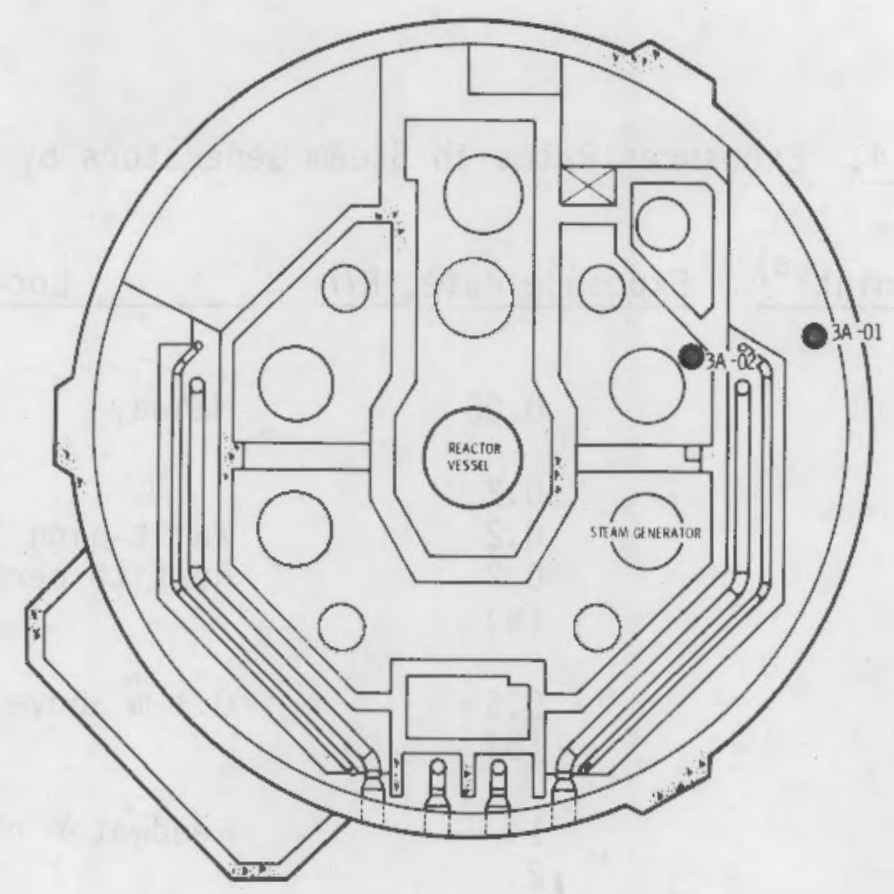

FIGURE 5. Source Locations in Containment Building at 23-m Elevation(8)

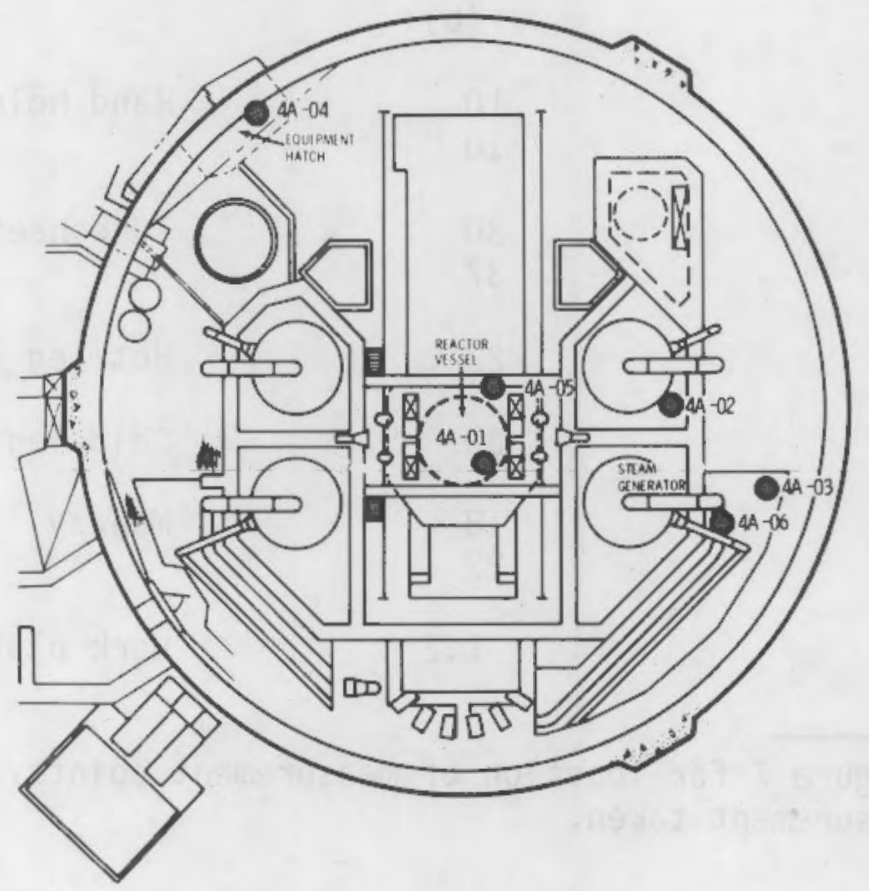

FIGURE 6. Source Locations in Containment Building at Operating $F$ loor and Above ( $\geq 28-m$ Elevation) (8) 
TABLE 4. Exposures Rates in Steam Generators by Location ${ }^{(8)}$

$\underline{\text { Measurement Point }}$ (a) Exposure Rate, $R / h$

\section{1}

$$
2
$$

3

4

5

6

7

8

9

10

11

12

13

14

15

16

17

18

19

20

21

22

23

24
0.05

0.2

0.2

0.2

(b)

0.5

(b)

\section{1}

2

2

(b)

3.5

10.5

10.5

(b)

10

10

30

37

22

30

18

22

1.2
Location

Manway

Waist-high in center of and next to perforated plates

$0.3 \mathrm{~m}$ above deck plate

Feedwater ring

Flow resistance plate

Hand hole

Tubesheet

Hot leg

Cold leg

Manway

Work platform

(a) See Figure 7 for location of measurement points.

(b) No measurement taken. 


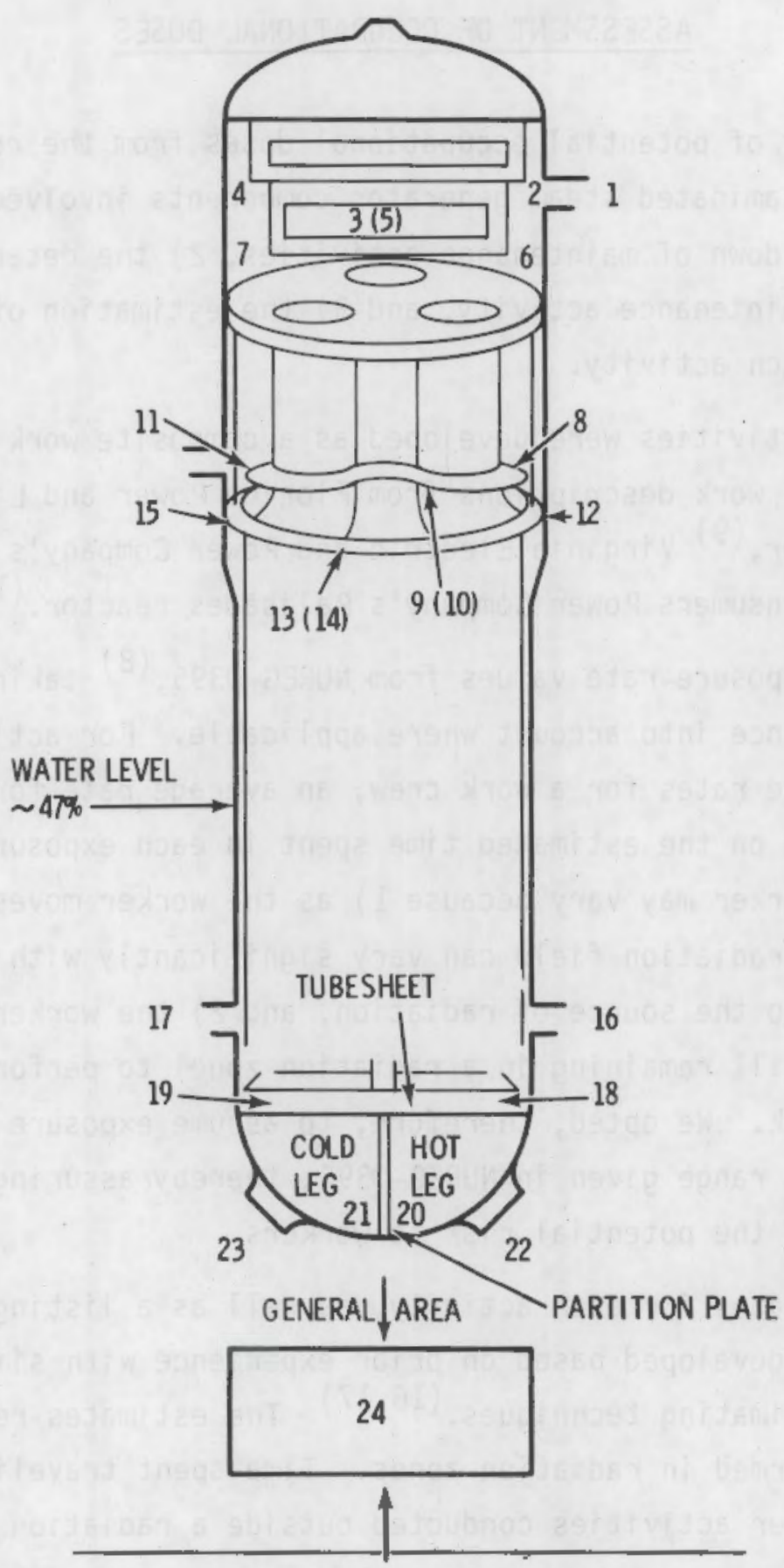

FIGURE 7. Source Locations in Steam Generator(8)

Note: Points in parentheses are located $180^{\circ}$ opposite those shown. Steam generator water level is at zero in the primary and at $\sim 47 \%$ in the secondary side. 


\section{ASSESSMENT OF OCCUPATIONAL DOSES}

The assessment of potential occupational doses from the removal and replacement of contaminated steam generator components involved three tasks: 1) a detailed breakdown of maintenance activities, 2) the determination of exposure rate by maintenance activity, and 3) the estimation of man-hour requirements for each activity.

Maintenance activities were developed as a composite work description based on individual work descriptions from Florida Power and Light Company's Turkey Point reactor, ${ }^{(9)}$ Virginia Electric and Power Company's Surry reactor, (10) and Consumers Power Company's Palisades reactor. (15)

We selected exposure-rate values from NUREG-0395, (8) taking temporary shielding and distance into account where applicable. For activities involving various exposure rates for a work crew, an average rate for the activity was developed based on the estimated time spent in each exposure zone. The actual dose to a worker may vary because 1) as the worker moves around within the task area, the radiation field can vary significantly with the worker's location relative to the source of radiation, and 2) the worker may leave the task area (while still remaining in a radiation zone) to perform support work related to that task. We opted, therefore, to assume exposure rates to be at the high end of the range given in NUREG-0395, thereby assuring that we are not underestimatimg the potential risk to workers.

Man-hour estimates for each activity, as well as a listing of the personnel involved, were developed based on prior experience with similar activities and on standard estimating tecnniques. $(16,17)$ The estimates represent manhours of work performed in radiation zones. Time spent traveling to and from work areas, and other activities conducted outside a radiation zone, were not included.

The product of the exposure rate $(R / h)$ and the man-hours needed for each maintenance activity, times a conversion factor ( $R$ to rem), yielded the activity dose (man-rem). The individual activity doses were then summed to obtain the total occupational dose for the project. 
Estimates of the dose received by health physics personnel were based on the assumption that health physicists were always near work areas, but not in the highest radiation zones. It was estimated that $10 \%$ to $15 \%$ of the dose received by other workers for any phase of the operation would be received by health physics personnel. The range was based on information in NUREG-0482, which shows that 6.8 of the total exposure at lignt water reactors is received by health physicists, and on Asnmore and Grogan's paper, (19) which shows a range of $2.9 \%$ to $14.5 \%$ for the dose to health physics personnel at Canadian reactor sites.

The maintenance activities involved in the preparation for the removal of contaminated steam generator components, the components' removal, and the installation of replacement components are listed in Taoles 5 to 7 , respectively. (Cut lines for detaching the components are shown in Figures 8 to 10.) For eacn step of these procedures, the tables also show which workers perform the job; the man-hours needed; the exposure rate involved; and the dose resulting from the combination of man-hours, exposure rate, and the conversion factor.

\section{DISCUSSION OF ESTIMATED GENERIC DOSES}

The total occupational doses estimated for each phase of maintenance activity on a single steam generator are listed below.

\begin{tabular}{lll} 
Activity Pnase & & Man-Rem \\
\hline Post-shutdown preparation & & $270-310$ \\
Removal of lower assembly & & $290-420$ \\
Installation of replacement & & $240-830$ \\
lower assembly & & $800-1500$ \\
Total &
\end{tabular}

The ranges represent differences in dose resulting from various approaches to cutting steain generator piping. Cutting the steam generator at the reactor coolant piping, for example, leads to higher doses than does cutting it at the channel head (see Table 6, activity number 4, and Table 7, activity number 10). 
We used a conservative approach when choosing exposure rates for estimating occupational doses. In most cases, this conservative approach results in an overestimate of the dose that will actually be received. Devices for remote cutting and welding are available and their use could substantially reduce the man-rem estimates for some operations. We assumed that they would be used on the channel head cut. These techniques could also be applied to the reactor coolant piping cuts. An additional reduction in dose could be achieved by keeping the water level on the secondary side of the steam generator as high as possible. Table 8 illustrates how much the radiation dose could be reduced through these means.

All of the estimates given in this section are for a generic case. Occupational dose estimates can vary widely from plant to plant because engineering approaches to the same problem may differ and radiation exposure rates will also differ. In this report, we have attempted to estimate an upper bound for the types of occupational doses that might be expected during steam generator removal and replacement. With prudent engineering controls and administrative techniques, the occupational doses actually encountered will be less than those given here.

\section{VARIABLES THAT AFFECT DOSES AT INDIVIOUAL PLANTS}

During post-shutdown preparation, several tasks may vary widely from plant to plant. Depending on the configuration of the containment building and the locations planned for the cuts on the steam generators, the amount of scaffolding reeded could vary considerably. The amount of scaffolding is directly related to the occupational dose received during its construction and installation.

The amount of concrete that must be removed to gain access to a steam generator and remove it from containment can vary substantially. At Surry, only a portion of the biological shields around the steam generators must be removed. At Turkey Point, large amounts of flooring and some concrete around the equipment hatch must be removed, as well as the shielding around the steam generators. At Palisades, a hole may have to be made in the containment wall 
in order to move the steam generator out. Each operation will involve a different amount of effort in a different radiation field and, therefore, a different occupational dose.

The amount of time workers would need to spend removing insulation from pipes in radiation zones could be considerably shortened if snap-on insulation were used.

Containment envelopes are clearly needed to prevent the spread of airborne contamination during some operations, such as cutting the reactor coolant piping. Other piping and components may not be as highly contaminated and would not need control structures. At Surry Unit 2, however, 1ocal control structures and ventilation systems were used for almost every pipe cut.

A number of removal and installation tasks can also be approached in various ways. Locating and removing small pipes and instrument lines can be time consuming and lead to considerable occupational dose. The use of highly accurate as-built drawings will decrease the time spent searching for these pipes and lines, and system surveys to locate them before workers are sent in to cut them may help reduce the occupational dose.

The location of cuts at the lower end of the steam generator -- at the reactor coolant piping or at the channel head, for example -- can lead to a wide range of occupational dose estimates; the two options mentioned involve extremely different approaches to the same engineering problem. Other mechanisms for disconnecting the lower portion of the steam generator from the primary coolant system can also be devised. Whatever approach is taken, all possible exposure pathways must be considered. Some options may at first analysis seem benefical from an engineering standpoint, but a more thorough analysis will reveal too high a cost in terms of occupational dose. In some instances, only one approach may be feasible because of the layout of the facility. In this and all cases, every effort should be made to keep occupational doses as low as is reasonably achievable.

The steam generator support system can differ dramatically from one plant to another. At Surry, for instance, the steam generators are hung from 
supports, which had to be removed before the steam generator could be moved. At Turkey Point, the generators are supported from below and the support system will not have to be removed.

The means of removing the steam generators from containment varies for different reactors. Some plants (such as Palisades) may need to cut a hole in the containment building. Others (such as Surry) may be able to use a laydown area within the containment building, put the steam generator on a transporter, and move it directly out through the equipment hatch. At still other plants (such as Turkey Point), extensive rigging may be needed to maneuver the steam generator slowly out of the equipment hatch. These approaches will require widely varying types and numbers of workers and varying times to accomplish the tasks.

If portions of reactor coolant piping are cut out of the primary system, two options are available. The pipe can be reused after it is decontaminated and prepared for welding, or it can be disposed of and new pipe purchased to install in the system. On the other hand, if the channel head is cut rather than the reactor coolant piping, no piping needs to be handled. All of the possible options that accompany the handling of reactor coolant piping can have vastly different impacts on occupational dose.

These examples have been given to illustrate the widely varying approaches and situations possible at different reactors. These variations in operations will result in a range of occupational dose estimates.

\section{COMPARISON OF GENERIC DOSES WITH UTILITIES' DOSE ESTIMATES}

Worker dose estimates from VEPCO's Surry Power Station, (7) Consumers Power Company's Palisades plant, (15) and Florida Power and Light (FPlLL) company's Turkey Point power station ${ }^{(9)}$ are compared with the results of our generic analyses in Table 9. Although comparison is difficult because of varying levels of detail among the estimates, the utilities' dose estimates are consistently lower than our conservative, generic estimates. The differences among the estimates are the result of differing procedures and radiation exposure rates from site to site. 
High-exposure activities are generally those involving work in the vicinity of reactor coolant piping or the channel head area of the steam generator. Specific high-exposure activities include the following:

- cutting and removing reactor coolant piping

- cutting the steam generator at the channel head

- removing steam generator supports

- welding reactor coolant piping or the channel head.

Other activities in relatively low-radiation zones result in high exposures because of the large number of man-hours involved. 


\section{TABLE 5. Post-Shutdown Preparation (per steam generator)}

\section{Maintenance Activity Description}

1. Unload entire core, remove fuel to spent fuel storage area, and drain primary system.

2. Survey containment work areas; perform local decontamination and general area cleanup to reduce possibility of airborne contamination; shield areas where necessary.

3. Install cover over reactor cavity to protect the reactor vessel and associated equipment and to provide a contiguous work area. (b)

4. Assemble special prefabricated scaffolding to permit access to all work areas.

5. Remove portion of biological shield wall and transport debris from the contaiment area.(c)

6. Remove insulation from steam generators, feedwater piping, steamine piping, reactor coolant piping, and other components and transport debris from the containment area.

7. Decontaminate exterior of piping and components, and do general cleanup.

8. Install local control structures, such as tents, ducting, temporary fij)ters, etc., where airborne contamination may be

9. Install steam generator transport system (e.g., rails) inside the containment area and on equipment hatch.

10. Inspect and test containment area's polar crane.

11. Cut hole in contaiment building for removal of steam generator.

12. Perform health physics services: radiation monitoring and surveys.

\begin{tabular}{|c|c|c|c|}
\hline $\begin{array}{r}\text { Exposure } \\
\text { Rate, } R / h \\
\end{array}$ & $\begin{array}{l}\text { Personnel } \\
\text { Involved }\end{array}$ & $\begin{array}{c}\text { Event } \\
\text { Duration, } \\
\text { man-h } \\
\end{array}$ & $\begin{array}{l}\text { Dose, } \\
\text { man-rem }\end{array}$ \\
\hline 0.03 & $\begin{array}{l}\text { Operators } \\
\text { Laborers }\end{array}$ & 650 & 20 \\
\hline $0.1(a)$ & $\begin{array}{l}\text { Laborers } \\
\text { Health } \\
\text { physics } \\
\text { technicians }\end{array}$ & 240 & 24 \\
\hline 0.05 & Boilermakers & 120 & 6 \\
\hline 0.2 & Carpenters & 80 & 16 \\
\hline 0.1 & Laborers & 140 & 14 \\
\hline 0.1 & Pipefitters & 320 & 32 \\
\hline 0.1 & Laborers & 163 & 16 \\
\hline 0.2 & Carpenters & 576 & 115 \\
\hline 0.01 & Laborers & 500 & 5 \\
\hline 0.01 & $\begin{array}{l}\text { Millwrights } \\
\text { Operators } \\
\text { Laborers }\end{array}$ & 128 & 1.3 \\
\hline 0.01 & & $286(e)$ & 29 \\
\hline $0.01-0.1$ & $\begin{array}{l}\text { Health } \\
\text { physics } \\
\text { technicians }\end{array}$ & & 25 \\
\hline
\end{tabular}

a) Exposure rate differs from that given in NUREG/CR-0199.

b) Heavy duty steel is used for the cover.

c) $25 \%$ of biological shields removed - all reinforced concrete.

d) Around reactor coolant piping.

e) Hours for work in radiation zone. Additional work will be performed outside the radiation zone. technicians

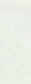

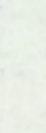




\section{TABLE 6. Removal of Lower Steam Generator Assembly (per steam generator)}

\section{Maintenance Activity Description}

1. Remove miscellaneous small piping (such as blowdown piping) and instruments and controls (such as level transmitters), to and instruments and controls (such as a)

2. Cut steamline piping at the steam nozzle on upper shell and downstream, to allow a section of piping to be removed

3. Cut feedwater piping at its junction with upper shell and upstream from the junction, to allow a section of be removed.

4. Cut lower portion of steam generator either at reactor coolant piping or at channel head.
A. Cut and remove reactor coolant inlet and outlet piping (see Figure 8). A section of not leg (inlet) piping (an elbow) will be removed by cutting the pipe at the steam generator nozzle and on the out let side of the reactor coolant system isolation valve. A large section of cold leg (outlet) piping, consisting of two elbows and two straight sections, will be removed by cutting the pipe at the steam generator nozzle and upstream from the reactor coolant pump. (c)

B. Decontaminate channel head and tubesheet, and cut steam generator at channel head just be low tubesheet

(see Figures 9 and 10). (d)

Decontaminate interior of channel head

Cut divider plate inside channel head, (e)

\section{Exposure Personne1} Rate, R/h

Pipefitters

Duration,

160

0.1 Pipefitters $\quad 128$

0.1 Pipefitters 100

Pipefitters
Dose, man-rem

16
45

100
21
224

(a) Cut six $15-\mathrm{cm}$ pipes and six $51-\mathrm{cm}$ pipes.

(b) Piping is $2.5 \mathrm{~cm}$ thick.

(c) Pipe weld preparation not included in man-h estimates. Shielding is placed on reactor coolant pump and channel head.

(e) Assume decontamination factor of 4-5. 
TABLE 6. (Contd)

\section{Maintenance Activity Description}

5. Cut steam generator shell at the transition cone (see Figure 8).

6. Lift off upper shell using the polar crane and store in the containment area.

7. Cut steam generator wrapper and internal blowdown piping.(b)

8. Inspect and remove moisture separation equipment, feedwater ring, and other associated equipment. Plug all pipe ends to prevent spread of contamination and to reduce the radiation

9. Disassemble and/or remove steam generator supports and snubbers to allow the lower steam generator assembly to be
lifted by the polar crane. $(e)$

10. Lift the lower steam generator assembly from its supports using the polar crane.

11. Remove lower shell assembly from the containment area on transfer cart or through the equipment hatch.

12. During and after removal, clean and decontaminate the containment work area to the extent practicable.

13. Remove lower assembly from equipment hatch platform by means of mobile cranes and transport to interim location or directly to disposal site.

14. Remove cutaway pipe sections and contaminated wastes from containment area.

15. Dispose of steam generator (see Appendix A).

16. Perform health physics services: radiation monitoring and surveys.

\section{Exposure Rate, $R / h$}

0.1

0.

0.

0.02 (d) Pipefitters

$0.2 \quad$ Pipefitters

0.03 Millwrights Laborers

Ironworkers

Operators

0.03 Millwrights

Laborers

Ironworkers

Ironworker

0.05 Laborers

Ironworkers

Operators

Laborers

0.03 Laborers

0.01-0.1 Health

physics

technicians
360

Event

Duration, Dose,

man-h man-rem

149(a) 15

$20(a) \quad 2$

32 (c) $\quad 3.2$

$400 \quad 8$

(a) Time estimate differs from that given in NUREG/CR-0199.

(c) New time est imate due to change in approach since NUREG/CR-0199.

(d) Exposure rate differs from that given in NUREG/CR-0199.

(e) Requires minimal cutting. 
TABLE 7. Installation of Replacement Lower Assembly (per steam generator)

\section{Maintenance Activity Description}

1. Deliver replacement for steam generator lower assembly by barge and transport to containment area's equipment hatch.

2. Lift lower assembly from transporter onto the equipment hatch platform by means of mobile cranes. Move it through equipment hatch and into the containment area using the containment transport system.

3. Decontaminate channel head further if it was left in place.(a)

4. Transport lower assembly to a designated location in the containment area and upend it using the polar crane. Lift and move it to a position over the steam generator supports, then lower it into place in the supports. Temporary positioning devices (e.g., jacks) may be installed to facilitate positioning of the lower assembly without the use of the polar crane.

5. Reassemble and/or install steam generator support system

Install new moisture separation equipment, feedwater $r$ ing, and other internal compunents in upper shell. Prepare mating surface of upper shell for welding to lower assembly.

7. Place moisture separation equipment on lower assembly, weld stęam generator wrapper to the upper internals, and inspect.

8. Lift upper steam generator shell into place and align with lower assembly. Temporary positioning devices may be used to facilitate alignment without the use of the polar crane.

9. Weld upper and lower assemblies together, stress-relieve, and inspect.

a) A decontamination factor of several hundred is attainable.

b) Supports may already be in place.

(c) New time estimate due to change in procedure since NUREG/CR-0199.

d) Time est imate differs from that given in NUREG/CR-0199.

\section{Exposure Personnel} Rate, $R / h$

0.2

0.04
Millwrights
Laborers
Operators

Ironworkers

Pipefitters

540

0.01 Pipefitters 600

Pipef itters

$212(c)$

120

ronworkers

Millwrights

Operators

0.01 Ironworkers

$1930(d)$
27

Dose,

(n)

$\cdots$

3.2

6.4 


\section{TABLE 7. (Contd)}

\section{Maintenance Activity Description}

\begin{aligned} & Exposure $\begin{array}{l}\text { Personnel } \\ \text { Rate, } R / h\end{array} \\ &$\hline\end{aligned}

Event Duration, Dose, man-h man-rem

10. Install steam generator into reactor coolant system.

A. Install the reactor coolant piping. (a)

$\begin{array}{llcc}0.25 & \text { Pipefitters } & 2636(b) & 660 \\ 0.1 & & 1373 & 140 \\ 0.1 & & 40 & 4 \\ 0.01 & \text { Pipefitters } & 192 & 1.9 \\ 0.01 & \text { Pipefitters } & 150 & 1.5 \\ 0.01 & \text { Pipefitters } & 200 & 2 \\ 0.01 & \begin{array}{l}\text { Carpenters } \\ \text { Cement }\end{array} & 500 & 5 \\ 0.01 & \text { Laborers } & 70 & 0.7 \\ 0.01 & \text { Pipefitters } & 450 & 4.5 \\ 0.05 & \text { Carpenters } & 80 & 4 \\ 0.05 & \text { Carpenters } & 32 & 1.6 \\ 0.01 & \text { Lperators } & 500 & 5 \\ 0.01 & \text { Laborers } & & 27 \\ 0.01-0.1 & \text { Health } & & 30-65\end{array}$

B. Weld steam generator shell to channel head.(c) Weld divider plate to tubesheet.

11. Fitup, weid, and insoect main steam piping.

12. Fitup, weld, and inswect feedwater piping.

13. Install miscellaneous piping (e.g., blowdown), instrumentation and controls that were removed.

14. Reconstruct biological shield wall and repair crane wall and other concrete structures that were chipped.

15. Clean affected systenis and work areas.

16. Install insulation.

17. Remove scaffolding.

18. Remove cavity cover.

19. Reconstruct contaimeit building wall.

20. Reload core.

21. Perform health physics services: radiation monitoring and surveys.

(a) Pipe weld preparation included. Hands-on welding assumed.

(b) Time est inate differs from that given in NUREG/CR-0199.

(c) Welding must be done remotely.

(d) Hours for work in radidtion zone. Additional work will be performed outside the radiation zone. 


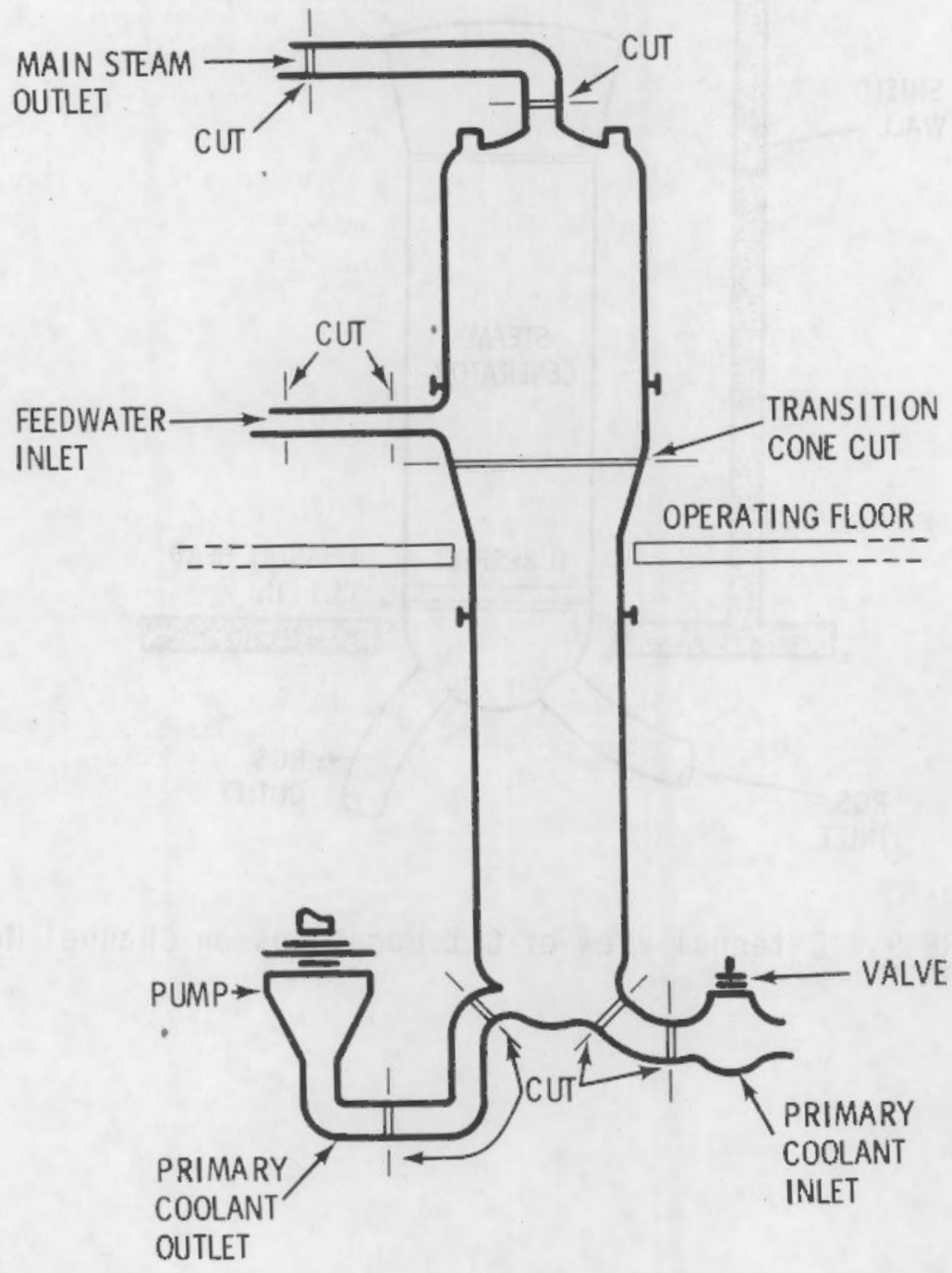

FIGURE 8. Cut Locations on Reactor Coolant Piping 


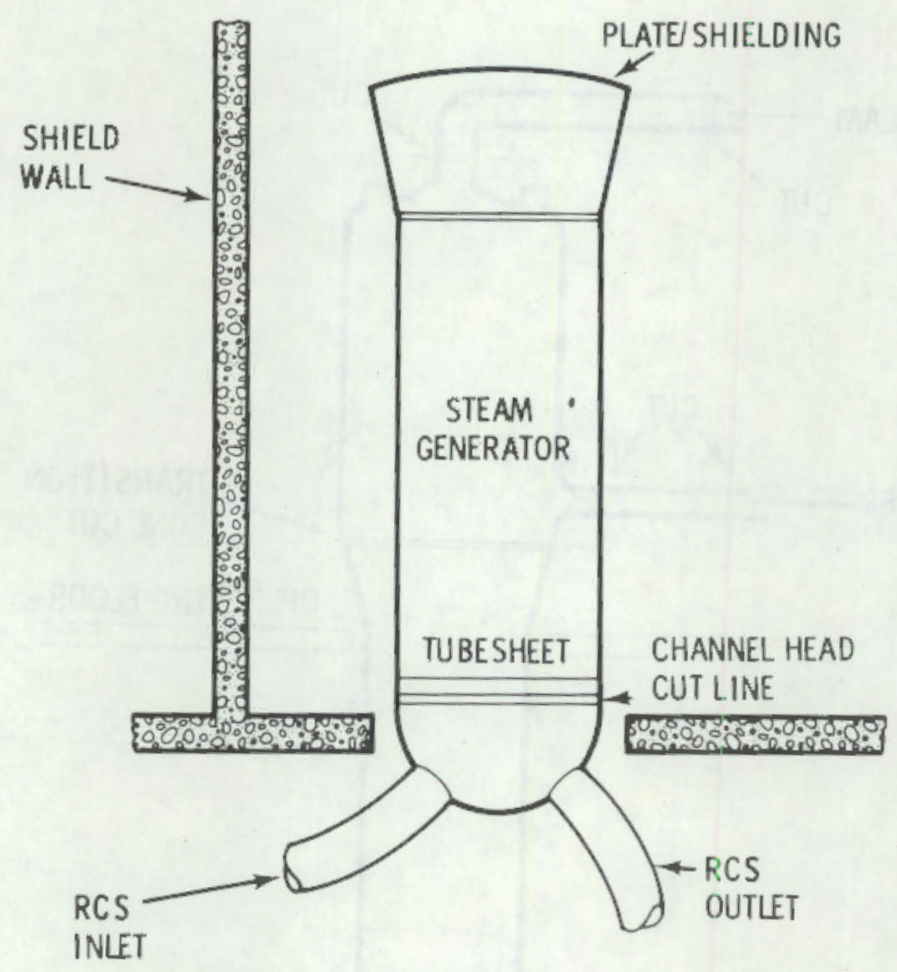

FIGURE 9. External View of Cut Locations on Channel Head 


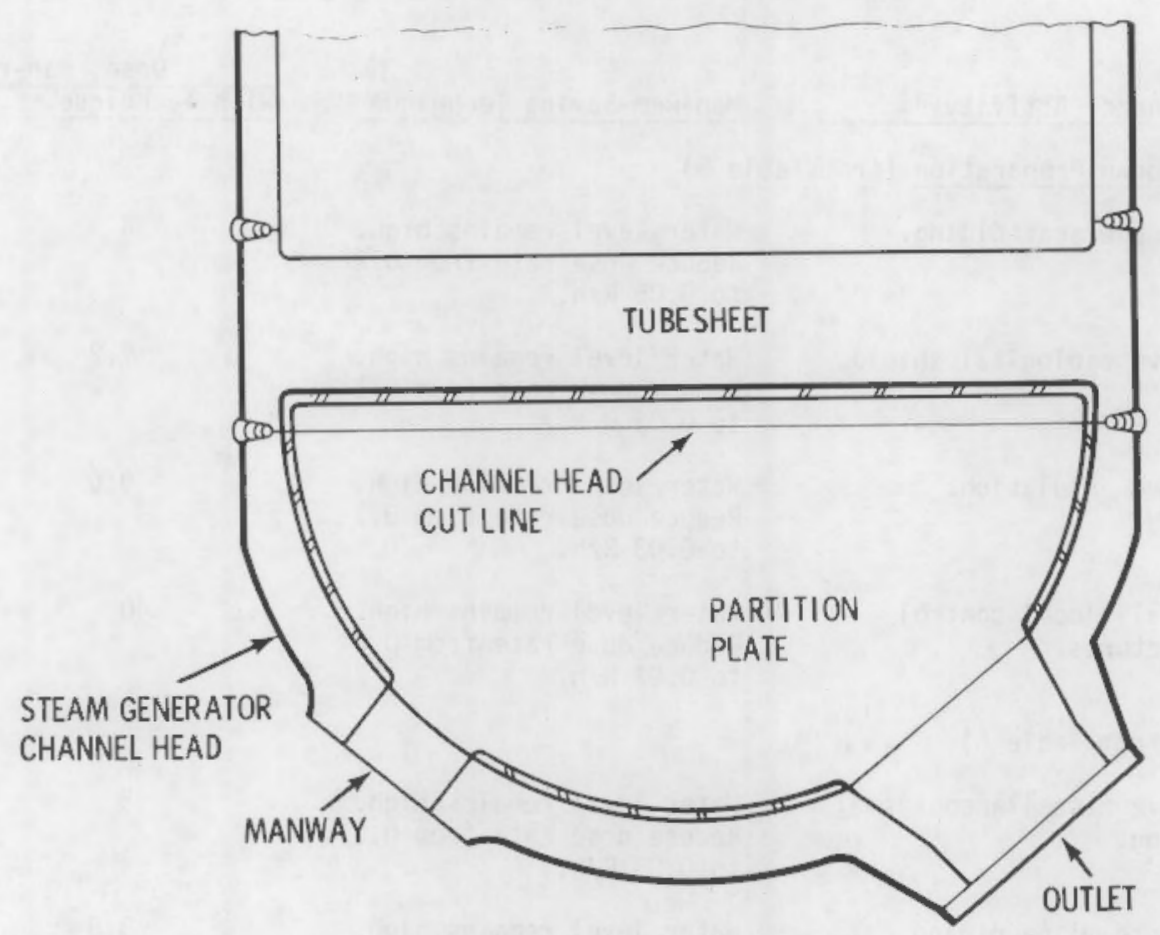

FIGURE 10. Cross-Sectional View of Channel Head Cut Line 
TABLE 8. Dose Reductions Possible Through Man-Rem-Saving Techniques

Maintenance Activity(a) - Man-Rem-Saving Technique

Dose, man-rem With Technique Without

4. Assemble scaffolding. Water level remains high. Reduce dose rate from 0.2 to $0.05 \mathrm{R} / \mathrm{h}$.

5. Remove biological shield. Water level remains high. Reduce dose rate from 0.1 to $0.03 \mathrm{R} / \mathrm{h}$.

6. Remove insulation.

Water level remains high. Reduce dose rate from 0.1 to $0.03 \mathrm{R} / \mathrm{h}$.

8. Install local control structures.

Water level remains high. Reduce dose rate from 0.2 to $0.07 \mathrm{R} / \mathrm{h}$.

4

7.2

9.6

32

40

115

Removal (from Table 6)

1. Remove miscellaneous small piping.

2. Cut steamline piping.

3. Cut feedwater piping.

4. A. Cut and remove reactor coolant inlet and outlet piping.

B. Cut channel head.

5. Cut steam generator shell.

9. Disassemble steam generator supports and remove lower assemblies.

\section{Installation (from Table 7)}

10. A. Install reactor coolant piping.

B. Weld steam generator to channel head.
Water level remains high. Reduce dose rate from 0.1 to $0.03 \mathrm{R} / \mathrm{h}$.

Water level remains high. Reduce dose rate from 0.1 to $0.03 \mathrm{R} / \mathrm{h}$.

Water level remains high. Reduce dose rate from 0.1 to $0.03 \mathrm{R} / \mathrm{h}$.

Use remote cutting device. radiation zone.

Use remote cutting device. Reduce number of man-h in radiation zone.

Same as 4.

5

3.8

5

100

Water level remains high during support disassembly. Reduce dose rate from 0.2 to $0.05 \mathrm{R} / \mathrm{h}$.

Use remote welding device. Reduce number of man-hr in radiation zone.

Jse remote welding device.

144

1000 Reduce number of man- $h$ in

(a) Activity numbers correspond to those in Tables 5-7. 
TABLE 9. Comparison of Generic and Utilities' Occupational Dose Estimates

\begin{tabular}{|c|c|c|c|c|}
\hline \multirow[b]{2}{*}{ Phase of Operation } & \multicolumn{4}{|c|}{ Dose Estimate, man-rem (a) } \\
\hline & Generic & $\begin{array}{l}\text { VEPCO } \\
\text { Surry }(10)\end{array}$ & $\begin{array}{c}F P \& L \\
\text { Turkey Point }(9) \\
\end{array}$ & $\begin{array}{c}\text { Consumers } \\
\text { Palisades (15) }\end{array}$ \\
\hline Preparation & $730-830$ & 599 & 283 & 473 \\
\hline Removal & $780-1200$ & 560 & 1016 & 282 \\
\hline Installation & $620-2300$ & 448 & 644 & 764 \\
\hline Miscel1 aneous & $260-390$ & 429 & 116 & - \\
\hline Total & $2400-4700$ & 2036 & 2059 & 1519 \\
\hline
\end{tabular}

(a) The generic, Surry, and Turxey Point estimates are for the removal of three steam generators; the Palisades estimate is for the removal of two steam generators. 


\section{ESTIMATED RELEASES OF RADIONUCLIDES TO THE ENVIRONMENT}

AND COMPARISON WITH RELEASES AT SURRY

Contamination levels in and around steam generators after 3 to 6 years of commercial operation were determined based on information contained in NUREG-0395, (8) NRC Dockets 50-250 and 50-251, (9) a Babcock a Wilcox report, (11) Ayres' Decontamination of Nuclear Reactors and Equipment, (12) and a Westinghouse document. (13) Table 10 lists the gross contamination in the reactor piping and steam generator systems, $(8,9)$ and Table 11 gives a breakdown of contamination levels by radionuclide for a steam generator channel head. (9)

\section{AIRBORNE RELEASES}

The primary airborne releases of radionuclides during steam generator removal are due to 1) cutting the reactor coolant piping or the channel head (depending on the approach used) and 2) cutting other system piping. Containment envelopes are used when cutting the reactor coolant piping or the channel head. These containment envelopes have a HEPA filter in their ventilation system and are exhausted through the plant ventilation system. For other cutting operations, no containment envelopes are required. For our calculations, we assumed that all HEPA filters are preceeded by a demister, which is necessary to retain filter integrity. Segmenting the steam generator at the transition cone and the internal wrapper does not contribute significantly to airborne releases because the contamination levels on the secondary side of the generator are several orders of magnitude below those on the primary side.

Airborne releases were calculated as follows:

Cutting the reactor coolant piping

1. Four cuts with a $0.95-\mathrm{cm}$ kerf are made in 86-Cn-ID pipe.

2. $4 \times 0.95 \times 86 \pi=1030 \mathrm{~cm}^{2}$ of material vaporized.

3. The contamination lever on the interior of the piping is $86 \mu \mathrm{C} / \mathrm{cm}^{2}$ (see Table 10). 
4. $1030 \mathrm{~cm}^{2} \times 86 \mu \mathrm{Ci} / \mathrm{cm}^{2}=8.9 \times 10^{4} \mu \mathrm{Ci}$ released.

5. With a decontamination factor $(20)$ of $10^{4}$ (two HEPA filters preceded by demisters), release to the atmosphere is $8.9 \mu \mathrm{C}$ i per steam generator.

Cutting the channel head

1. A single cut with a $0.95-\mathrm{cm}$ kerf is made in 274-cm-ID pipe.

2. $0.95 \times 274 \pi=820 \mathrm{~cm}^{2}$ of material vaporized.

3. The contamination level on the interior of the channel head is $68 \mu \mathrm{Ci} / \mathrm{cm}^{2}$ (see Table 10).

4. $820 \mathrm{~cm}^{2} \times 68 \mu \mathrm{Ci} / \mathrm{cm}^{2}=5.6 \times 10^{4} \mu \mathrm{Ci}$ released.

5. With a decontamination factor $(20)$ of $10^{4}$ (two HEPA filters preceded by demisters), release to the atmosphere is $5.6 \mu \mathrm{Ci}$ per stean generator.

Cutting other system piping

1. Single cuts with a $0.95-\mathrm{cm}$ kerf are made in six 15-cm-ID and six 5-cm-ID pipes, and two cuts are made in one 76-cm-ID (steam line) and one 36-cr-ID (feedwater) pipe.

2. $0.95 \times(6 \times 15 \pi+6 \times 5 \pi+2 \times 76 \pi+2 \times 36 \pi)=1.0 \times 10^{3} \mathrm{~cm}^{2}$ of material vaporized.

3. The contamination level on the interior of the pipes is 6.? $\mu \mathrm{Ci} / \mathrm{cm}^{2}$ (see Table 10).

4. $1.0 \times 10^{3} \mathrm{~cm}^{2} \times 6.2 \mu \mathrm{Ci} / \mathrm{cm}^{2}=6.4 \times 10^{3} \mu \mathrm{Ci}$ released

5. With a decontamination factor $(20)$ of $10^{2}$ (one HEPA filter preceded by a demister), release to the atmosphere is $64{ }_{\mu} \mathrm{C} i$ per steam generator.

Assuming three steam generators per reactor unit, the total release for cutting operations would be between $210 \mu \mathrm{C}$ per unit (if the channel head and 
other piping were cut) and $220 \mu \mathrm{C} i$ per unit (if the reactor coolant piping and other piping were cut). The radionuclide distribution would be very simitar to that $]$ isted in Table 11 .

The airoorne releases measured during the steam generator replacement at Surry Unit 2 were $101.3 \mathrm{Ci}$ of noble gases, $5.88 \times 10^{-6} \mathrm{Ci}$ of iodines, and $1.32 \times 10^{-3} \mathrm{Ci}$ of particulates. (7) Airborne releases from fuel unloading and reloading are included in the Surry measuremen:s. Refueling releases were not included in this report since steam generator removal and replacement would normally be done during a scheduled shutdown for refueling.

\section{WATERBORNE RELEASES}

The primary sources of liquid effluent during steam generator removal are the release of the reactor coolant and the discharge of laundry waste water. The calculation of radionuclide releases from these sources is described below. If all or part of the interior of the steam generator is decontaninated, the amount of liquid waste generated will be substanticily increased. Appendix A treats this aspect of steam generator repair in more detaii.

Reactor Coolant

The reactor coolant system must be drained and the water either discharged or, if enough space is available, stored before the steam generator can be removed. The amounts of waterborne radionuclides released through the discharge of reactor coolant were estimated using the contamination levels listed in Table 12 and assuming discharge of the reactor coolant about 30 days after plant shutdown. The decontamination factors assumed for waste-water processing equipment are listed in Taole 13 and are in accordance with NUREG-0017. The amount of reactor coolant water in the primary system was assumed to be approximately $1.9 \times 10^{8} \mathrm{~g} \cdot(9)$ The estimated amounts of each radionuclide released during discharge of the reactor coolant are listed in Table 14. Laundry Waste Water

Releases of radionuclides in laundry waste water were estimated using tine activities listed in Table 15 and assuming a discharge of approximately 
$100,0001 /$ day $^{(9)}$ for about 180 days. The decontamination factors that inight affect the laundry waste are listed in Table 13; nowever, processing of the laundry waste water is not anticipated for most plants. The estimated radionuclide releases from both treated and untreated laundry waste water are listed in Table 10 .

Laundry waste water was tne major source of waterborne releases during the replacement of stean generators at Surry Unit 2; the reactor coolant was not discharged. About $0.5 \mathrm{C} i$ was released in $14 \times 10^{6} 1$ of liquid during the replacement operations. (7)

\section{SOLID WASTES}

The solid wastes generated during the removal and replacement of steam generators include the plastic (or other material) and wood or metal used to construct containment envelopes and scaffolding; concrete removed from biological shielids, floors, and walls; HEPA filters; and a small amount of disposable clothing.

For each steam generator, approximately $50 \mathrm{~m}^{2}$ of plastic and $91 \mathrm{~m}$ of two-by-fours are used to construct containment envelopes around the reactor coolant piping. About $15 \mathrm{~m}^{3(6)}$ of concrete per steam generator are removed. Liquid slurry collected during the removal of concrete is solidified and sent to a disposal site. However, since the concrete is only slightly radioactive, the slurry needs no special handling. Several HEPA filters used in the containment envelope are disposed of following completion of the operation. Most of the clothing worn by workers is laundered, but some must be discarded. Rags and paper used during the operation are also packaged for disposal. All this material amounts to approximately $760 \mathrm{~m}^{3(5)}$ of low-activity waste per steam generator.

Insulation from the steam generator and associated piping must also be disposed of as waste. If leaks or spills have occurred, some of this insulation will be contaminated. 
If an opening is cut in the containment building wall, substantial amounts of concrete and rebar -- approximately $45 \mathrm{~m}^{3}$ of material -- must be discarded. Since mucn of this material has not been contaminated, some of it may be disposed of in a sanitary landfill.

Waste generated during welding operations is also disposed of as radioactive material. Material used to support and move the steam generator within containment, temporary shielding, scaffolding, the reactor cavity cover, etc., should not become contaminated during the operation and can therefore be reused. One exception to this is any temporary shielding used inside containment envelopes. This shielding may become contaminated and should either be disposed of or decontaminated.

Stearn generator replacement at Surry Unit 2 resulted in $1618 \mathrm{~m}^{3}$ of solid waste containing $63.6 \mathrm{Ci} .{ }^{(4)}$ This waste consisted of 1) contaminated insulation, structural materials, and coinponents not intended for reuse, 2) solidified decontamination solutions, and 3) contaminated paper waste, disposable protective clothing, and contamination control material. 
TABLE 10. Gross Contamination Levels by Location in Piping and Steam Generator

$\begin{array}{cc}\text { Component } & \begin{array}{c}\text { Contamination Level, } \\ \mathrm{HCi} / \mathrm{Cm}^{2}\end{array} \\ \begin{array}{cc}\text { Reactor coolant piping } \\ \text { Otner piping }\end{array} & 36 \\ \text { Steam generator } & 6.2 \\ \text { Primary side } & \\ \text { tubes } & 8.2 \\ \text { tubesheet } & 140 \\ \text { channel head } & 68 \\ \text { partition plate } & 140 \\ \text { Secondary side } & \sim 10^{-3}\end{array}$

TABLE 11. Contamination Levels by Radionuclide on Steam Generator Channel Head(a) (9)

\begin{tabular}{|c|c|c|c|}
\hline Radionuclide & $\begin{array}{l}\text { Activity, } \\
\underline{\mathrm{uC}} \mathrm{i} / \mathrm{cm}^{2}\end{array}$ & Radionuc lide & $\begin{array}{l}\text { Activity, } \\
\underline{\mu C} / / \mathrm{cm}^{2}\end{array}$ \\
\hline${ }^{51} \mathrm{Cr}$ & 1.35 & 131 I & 0.45 \\
\hline${ }^{54} \mathrm{Mn}$ & 2.03 & $132 \mathrm{I}$ & 0.45 \\
\hline${ }^{58} \mathrm{Co}$ & 25.03 & ${ }^{132} \mathrm{Te}$ & 0.45 \\
\hline${ }^{59} \mathrm{Fe}$ & 0.465 & ${ }^{137} \mathrm{Cs}$ & 0.067 \\
\hline${ }^{60} \mathrm{Co}$ & 19.7 & $140_{\mathrm{Ba}}$ & 0.45 \\
\hline $95 \mathrm{Zr}$ & 2.25 & $140_{L a}$ & 1.35 \\
\hline${ }^{95} \mathrm{Nb}$ & 3.15 & ${ }^{141} \mathrm{Ce}$ & 0.75 \\
\hline 99 Mo & 0.45 & ${ }^{144} \mathrm{Ce}$ & 3.72 \\
\hline \multirow[t]{2}{*}{$1103_{\mathrm{Ru}}$} & 1.5 & ${ }^{239} \mathrm{NP}$ & 4.8 \\
\hline & & Total & 68 \\
\hline
\end{tabular}

(a) The activities are based on actual Turkey Point data, extrapolated to $7 \mathrm{yr}$ of commercial operation. 
TABLE 12. Radionuclide Concentrations in Reactor Coolant(15)

\begin{tabular}{|c|c|c|c|c|c|}
\hline Radionuclide & $\begin{array}{c}\text { Half-Life, } \\
\text { days }\end{array}$ & $\begin{array}{c}\text { Concentration, } \\
\mu \mathrm{C} i / \mathrm{g}\end{array}$ & Radionuclide & $\begin{array}{l}\text { Half-Life, } \\
\text { days }\end{array}$ & $\begin{array}{c}\text { Concentration, } \\
\mu \mathrm{Ci} / \mathrm{g}\end{array}$ \\
\hline $3_{\mathrm{H}}$ & $4.51 E+03^{(a)}$ & $1.0 \mathrm{E}+00$ & ${ }^{106} \mathrm{Rh}$ & $3.46 E-04$ & $1.0 E-05$ \\
\hline${ }^{16} \mathrm{~N}$ & $8.22 E-05$ & $4.0 E+01$ & ${ }^{125 \mathrm{~m}_{\mathrm{Te}}}$ & $5.80 E+01$ & $2.9 E-05$ \\
\hline${ }^{5 l} \mathrm{Cr}$ & $2.77 E+01$ & $1.9 E-03$ & $127 \mathrm{~m}_{\mathrm{Te}}$ & $1.09 E+02$ & $2.8 E-04$ \\
\hline${ }^{54} \mathrm{Mn}$ & $3.13 E+02$ & $3.1 E-04$ & ${ }^{127} \mathrm{Te}$ & $3.90 E-01$ & $8.5 E-04$ \\
\hline${ }^{55_{\mathrm{Fe}}}$ & $9.86 E+02$ & $1.6 E-03$ & $129 \mathrm{~m}_{\mathrm{Te}}$ & $3.36 E+01$ & $1.4 E-03$ \\
\hline${ }^{59} \mathrm{Fe}$ & $4.46 E+01$ & $1.0 E-03$ & ${ }^{129} \mathrm{Te}$ & $4.83 E-02$ & $1.6 \mathrm{E}-03$ \\
\hline${ }^{58} \mathrm{Co}$ & $7.08 E+0 l$ & $1.6 E-02$ & $131 \mathrm{~mm}_{\mathrm{Te}}$ & $12.5 E+0$ & $2.5 E-03$ \\
\hline${ }^{60} \mathrm{Co}$ & $1.93 E+03$ & $2.0 E-03$ & $131 \mathrm{Te}$ & $1.74 E-02$ & $1.1 E-03$ \\
\hline${ }^{83} \mathrm{Br}$ & $9.96 €-02$ & $4.8 E-02$ & ${ }^{132} \mathrm{Te}$ & $3.26 E+00$ & 2.7E-02 \\
\hline${ }^{84} \mathrm{Br}$ & $2.21 \mathrm{E}-02$ & $2.6 E-03$ & $130 \mathrm{I}$ & $5.15 E-01$ & $2.1 \mathrm{E}-03$ \\
\hline $85_{\mathrm{Br}}$ & $1.99 \mathrm{E}-03$ & $3.0 E-04$ & 131 & $8.04 E+0$ & $2.7 \mathrm{E}-0 \mathrm{l}$ \\
\hline${ }^{36} 6_{R b}$ & $1.87 E+01$ & $8.5 E+01$ & $132 \mathrm{I}$ & $9.5 E-02$ & $1.0 E-01$ \\
\hline $8_{\mathrm{Rb}}$ & $1.24 \mathrm{E}-02$ & $1.0 E-01$ & $133 \mathrm{I}$ & $8.67 E-01$ & $3.8 \mathrm{E}-0 \mathrm{l}$ \\
\hline${ }^{39} s r$ & $5.06 E+01$ & $3.5 E-04$ & $134 \mathrm{I}$ & $3.65 E-02$ & $4.7 E-02$ \\
\hline $90_{5 r}$ & $1.04 E+04$ & $1.0 E-05$ & $135_{1}$ & $2.75 E-01$ & $1.9 E-01$ \\
\hline $91 s r$ & $3.96 E-01$ & $6.5 E-04$ & ${ }^{134} \mathrm{Cs}$ & $7.53 \mathrm{E}+02$ & $2.5 E-02$ \\
\hline $90_{Y}$ & $1.67 \mathrm{E}+00$ & $1.2 E-06$ & ${ }^{136} \mathrm{Cs}$ & $1.31 E+01$ & 1. $3 E-02$ \\
\hline $91 m_{Y}$ & $3.4 E-02$ & $3.6 \mathrm{E}-04$ & $137 \mathrm{Cs}$ & $1.10 E+-4$ & $1.3 \mathrm{E}-02$ \\
\hline $91_{Y}$ & $5.81 E+01$ & $6.4 E-05$ & $137 \mathrm{~m}_{\mathrm{Ba}}$ & $1.78 E-03$ & $1.6 \mathrm{E}-02$ \\
\hline $93 y$ & $4.21 E-01$ & $3.4 E-05$ & $140 \mathrm{Ba}$ & $1.28 \mathrm{E}+0 \mathrm{l}$ & $2.2 E-04$ \\
\hline${ }^{95} \mathrm{Zr}$ & $6.40 E+01$ & $6.0 \mathrm{E}-05$ & ${ }^{140} \mathrm{La}$ & $1.68 \mathrm{E}+0$ & $1.5 E-04$ \\
\hline${ }^{95} \mathrm{Nb}$ & $3.52 \mathrm{E}+0 \mathrm{~L}$ & $5.0 E-05$ & 141 & $3.25 E+01$ & $7.0 E-05$ \\
\hline${ }^{99} \mathrm{Mo}_{\mathrm{O}}$ & $2.75 E+0$ & $8.4 E-02$ & $143 \mathrm{Ce}$ & $1.38 E+0$ & $4.0 E-05$ \\
\hline $99 \pi_{T}$ & $2.51 E-01$ & 4. $8 \mathrm{E}-02$ & 144 & $2.84 E+02$ & 3. $3 E-05$ \\
\hline${ }^{103} \mathrm{Ru}_{\mathrm{u}}$ & $3.93 \mathrm{E}+01$ & $4.5 E-05$ & $143 \mathrm{Pr}$ & $1.36 E+01$ & $5.0 \mathrm{E}-05$ \\
\hline${ }^{106_{R u}}$ & $3.68 E+02$ & $1.0 E-05$ & $144 \mathrm{Pr}$ & $5.00 E-03$ & $3.3 E-05$ \\
\hline $103 m_{R h}$ & 3. $90 \mathrm{E}-02$ & $4.5 E-05$ & ${ }^{239} \mathrm{~Np}$ & $2.35 E+00$ & 1. $2 \mathrm{E}-03$ \\
\hline
\end{tabular}

(a) $4.51 \mathrm{E}+03=4.51 \times 10^{3}$

TABLE 13. Decontamination Factors Used to Calculate Radionuclide Releases in Liquids

Decontamination Factors

Process Equipment Tritium Iodines CS\&Rb Others

Mixed bed demineralizer

Radwaste evaporator

$1 \quad:$

Evaporator for laundry wastes

$1 \quad \therefore 0^{3}$

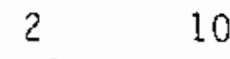

$1 \quad 1.0^{2}$

$10^{4} \quad 10^{4}$

$10^{2} \quad 10^{2}$ 
TABLE 14. Estimated Radionuclide Releases Due to Discharge of Reactor Coolant Water(a)

\begin{tabular}{|c|c|}
\hline Radionuclide & Release, $\mathrm{Ci}$ \\
\hline $\begin{array}{l}3 \mathrm{H} \\
51 \mathrm{Cr} \\
54 \mathrm{Mn} \\
55 \mathrm{Fe} \\
59 \mathrm{Fe}\end{array}$ & $\begin{array}{l}1.9 \mathrm{E}+02(\mathrm{~b}) \\
1.7 \mathrm{E}-06 \\
5.5 \mathrm{E}-07 \\
3.0 \mathrm{E}-06 \\
1.2 \mathrm{E}-06\end{array}$ \\
\hline $\begin{array}{l}58 \mathrm{CO} \\
60 \mathrm{CO} \\
86 \mathrm{Rb} \\
89 \mathrm{Sr} \\
90 \mathrm{Sr}\end{array}$ & $\begin{array}{l}2.3 \mathrm{E}-05 \\
3.8 \mathrm{E}-06 \\
2.6 \mathrm{E}-07 \\
4.4 \mathrm{E}-07 \\
1.9 \mathrm{E}-08\end{array}$ \\
\hline $\begin{array}{l}90 Y \\
91 Y \\
95 \mathrm{Zr} \\
95 \mathrm{Nb} \\
99 \mathrm{MO}\end{array}$ & $\begin{array}{l}1.9 \mathrm{E}-08 \\
8.5 \mathrm{E}-08 \\
8.2 \mathrm{E}-08 \\
5.3 \mathrm{E}-08 \\
8.3 \mathrm{E}-08\end{array}$ \\
\hline $\begin{array}{l}103 \mathrm{Ru} \\
106 \mathrm{Ru} \\
125 \mathrm{mTe} \\
127 \mathrm{mTe} \\
129 \mathrm{mTe}\end{array}$ & $\begin{array}{l}5.0 \mathrm{E}-08 \\
1.8 \mathrm{E}-08 \\
3.8 \mathrm{E}-08 \\
4.4 \mathrm{E}-07 \\
1.4 \mathrm{E}-06\end{array}$ \\
\hline $\begin{array}{l}131 \mathrm{mTe} \\
132 \mathrm{Te} \\
131 \mathrm{I} \\
133 \mathrm{I} \\
134 \mathrm{Cs}\end{array}$ & $\begin{array}{l}2.8 \mathrm{E}-13 \\
8.7 \mathrm{E}-08 \\
3.9 \mathrm{E}-04 \\
2.7 \mathrm{E}-13 \\
2.3 \mathrm{E}-04\end{array}$ \\
\hline $\begin{array}{l}136 \mathrm{Cs} \\
137 \mathrm{Cs} \\
140 \mathrm{Ba} \\
140 \mathrm{La} \\
141 \mathrm{Ce}\end{array}$ & $\begin{array}{l}2.5 \mathrm{E}-05 \\
1.7 \mathrm{E}-04 \\
8.2 \mathrm{E}-08 \\
1.2 \mathrm{E}-12 \\
7.0 \mathrm{E}-08\end{array}$ \\
\hline $\begin{array}{l}143 \mathrm{Ce} \\
144 \mathrm{Ce} \\
143 \mathrm{Pr} \\
239 \mathrm{~Np}\end{array}$ & $\begin{array}{l}2.1 \mathrm{E}-14 \\
5.8 \mathrm{E}-08 \\
2.0 \mathrm{E}-08 \\
3.3 \mathrm{E}-10 \\
\end{array}$ \\
\hline Total & $1.9 E+02$ \\
\hline
\end{tabular}

(a) For a power plant with three steam generators.

(b) $1.9 \mathrm{E}+02=1.9 \times 10^{2}$. 
TABLE 15. Radionuclide Concentrations in Laundry waste Water (6)

\begin{tabular}{cc} 
Padionuclide & Concentration, $\lrcorner \mathrm{Ci} / \mathrm{cm}^{3}$ \\
\hline${ }^{54} \mathrm{Mn}$ & $7.3 \mathrm{E}-7^{(\mathrm{a})}$ \\
${ }^{58} \mathrm{CO}$ & $6.7 \mathrm{E}-6$ \\
${ }^{50} \mathrm{CO}_{\mathrm{O}}$ & $5.0 \mathrm{E}-6$ \\
$131_{\mathrm{I}}$ & $1.1 \mathrm{E}-7$ \\
$134_{\mathrm{CS}}$ & $6.5 \mathrm{E}-7$ \\
$137 \mathrm{CS}$ & $5.4 \mathrm{E}-6$
\end{tabular}

(a) $7.3 E_{-7}=7.3 \times 10^{-7}$.

TABLE 16. Estimated Radionuclide Releases Due to Discharge of Laundry Waste Water(a)

\begin{tabular}{|c|c|c|}
\hline \multirow[b]{2}{*}{ Radionuclide } & \multicolumn{2}{|c|}{ Release, $\mathrm{Ci}$} \\
\hline & With Processing & No Processing \\
\hline${ }^{54} \mathrm{Mn}$ & $1.1 E_{-4}(b)$ & $1.1 E-2$ \\
\hline${ }^{58} \mathrm{Co}$ & $1.0 E-3$ & 1. $0 E-1$ \\
\hline${ }^{60} \mathrm{Co}$ & $7.5 \mathrm{E}-4$ & $7.5 \mathrm{E}-2$ \\
\hline${ }^{131} 1_{I}$ & $1.7 \mathrm{E}-5$ & $1.7 E-3$ \\
\hline $134 \mathrm{Cs}$ & $9.8 \mathrm{E}-5$ & $9.8 \mathrm{E}-3$ \\
\hline${ }^{137} \mathrm{Cs}$ & $3.1 \mathrm{E}-4$ & $3.1 E-2$ \\
\hline Total & $2.2 E-03$ & $2.3 E-01$ \\
\hline
\end{tabular}

\footnotetext{
(a) For a power plant with three steam generators.

(D) $1.1 \mathrm{E}-4=1.1 \times 10^{-4}$.
} 


\section{OTHER SAFETY CONCERNS}

Fire protection and industrial safety and hygiene are as important as radiation protection during steam generator removal and replacement and also require careful planning, engineered safeguards, and administrative controis. The requirements of the Occupational Safety and Health Administration and NRC for construction safety, radiation zone work, and work with chemicals need to be carefuliy integrated into the project. Involving a safety engineer early in the planning of the project will help provide a safe environment for the steain generator workers. Following is a brief description of some of the items that should be covered by the fire protection and industrial safety and nygiene program.

Good housekeeping practices are essential to any safety program. Industrial safety should also cover the proper use of hard nats and eye protection, scaffolding construction, and the use of ladders for proper access to work levels. The industrial hygiene program should include the provision of adequate ventilation or respirator protection when chemical work (e.g., decontamination) or the cutting of heavy materials is necessary. The use of fire retardant materials, proper containers for the disposal of rags and other wastes and for the storage of flammable liquids (e.g., decontamination solutions), and adequate ventilation in areas where those liquids are stored are all part of fire protection, in addition to the proper placement of an adequate number of fire extinguishers. 


\section{LEARNING FROM EXPERIENCE: STEAM GENERATOR}

REPAIR OPERATIONS AT SURRY UNIT 2

During most of 1979 , steam generator repair jperations were being conducted at Surry unit 2. These successful operations were the first of their $k$ ind and a considerable amount of knowledge was gained. The operations pinpointed some of the health physics concerns that may arise during major maintenance work such as steam generator replacement: large numbers of workers with widely varying Dackgrounds must be trained in both the operational and the radiological aspects of their jobs; containment structures must be built and potentially large quantities of low-level radiological waste handled; and the radiation dose to workers and observers must be kept as low as is reasonably achievable.

\section{MANAGING LARGE NUMBERS OF WORKERS}

It is imperative to accurately anticipate how many people will report to work for a steam generator replacement. Handling a large number of workers takes considerable joint planning by neaith physicists and radiological engineers. Each worker may have to go through security, badging, the health physics station, whole-body counting, etc., a process that may result in long waiting lines and significant idle time in work areas while workers wait for a full crew to assemble. If the work areas are in radiation zones, some unnecessary radiation exposure may be received.

Over 1000 workers reoorted the first day at Surry Unit 2. This large number of workers was due to the use of double crews for many operations. These second crews, who spent most of their time in the containment building, were hired to reduce lost time in the event that a single crew was not sufficient to complete a task. Because this operation was the first of its kind, not all contingencies could be anticipated. The experience gained at Surry Unit 2 should help reduce the number of double crews needed for future steam generator replacements and, in turn, the occupational dose to workers in radiation zones. 
TRAINING WORKERS FOR THE JOB

Proper training is an important aspect of any extended maintenance outage if operations are to be conducted in a safe manner, in the minimum amount of time, and with proper protection of workers against radiation exposures. One of the best means of training workers is to use mockups. This method is frequently used for welding and cutting operations, but may also be employed for many other tasks if only to illustrate the size and complexity of the job.

An important lesson learned at Surry Unit 2 was that adequate health physics training is difficult to provide for a maintenance outage as large as a steam generator removal and replacement, in part because of the varied backgrounds and work experiences of the crews. Some of the difficulties that may be encountered during basic health physics training follow.

- Many of the workers may not have worked in a radiation zone before. They may not understand or appreciate the complexity and importance of the radiological problems encountered.

- If the health physics training course follows immediately after an orientation course or other training session, the workers may already be overloaded with new information, be fatigued, or have lost interest to the extent that they can no longer concentrate. In addition, some individuals may not be motivated to learn. This problem is difficult to overcome, and motivational training is not with in the scope of a health physics training course.

- The content of the training course, though adequate for normal operations, may not be sufficient for a major maintenance outage such as a steam generator replacement.

More emphasis must be placed on health physics training to ensure that workers properly understand the types of problems and the situations they will be encountering. Special attention must be given to individuals who have not previously worked in radiation zones or who lack the tecnnical background to understand complex radiological problems. Standard heaith physics training courses and the manner in which they are presented may have to be substantially changed in order to meet the training needs specific to a steam generator repair operation. 


\section{BRIEFING WORKERS}

An important part of planning is a thorough briefing of work crews just before they enter a radiation zone to perform a specific task. A briefing should include a thorough review of both operationel and radiological aspects of the job: the location of the job, the radiatior hazards associated with it, and the task involved. The use of worker briefings should reduce idle time in radiation zones as well as overall on-the-job time.

A postjob review can also be beneficial in helping to plan for similar jobs or work in the same area. It will bring out any problems encountered and any differences between what was anticipated and what was actually found. All worker briefings, both before and after the job, should be used to reinforce previous training and as a basis for revising training classes to account for new situations.

\section{BUILDING CONTAMINATION CONTROL STRUCTURES}

One of the most useful things learned during the Surry Unit 2 operation was the benefit of having a specialist make custom-fit shielding blankets and containment envelopes. A tentmaker was hired to design and build on site all lead wool blankets, gloveboxes, and containment envelopes. This practice reduced the amount of radiation streaming from the shielding used to protect workers and produced very effective control of airborne contamination.

HANOLING LOW-LEVEL WASTE

Coping with low-level radioactive waste may be a significant concern during steam generator repair operations. Plans must be made to minimize the amount of low-level waste and provide a quick and efficient means of removing the waste from containment Decause of 1 imited space. At Surry Unit 2, the volume of waste was affected most by the amount of disposable protective clothing needed for the large number of workers, by an extensive cleanup effort in the containment area that generated large amounts of rags, towels, and solidified liquid, and by the wood used in scaffolding and tent construction, which had to be disposed of Decause it was virtualiy impossiole to decontaninate. 
The amount of waste that will be generated can be anticipated with proper planning. A review of tasks and manpower needs will provide information on the amount of protective clothing that must be disposed of or laundered. Steam generator repairs are conducted in a confined space and it is important to minimize the volume of waste stored even temporarily in the containment area. Although the amount of waste produced during containment cleanup cannot be precisely defined, logistical planning can lead to the removal of the waste before a congestion problem results. The amount of wood to be disposed of can be substantially reduced by using metal scaffolding or by covering the wood with plastic or paint. Metal can De decontaminated with relative ease. plastic or paint can be stripped or cleaned and the wood used again.

Littie radiation exposure comes from working with or near low-level waste, but tne amounts generated and packaged in the containment area can aggravate already crowded conditions. Almost any method of reducing the amount of waste is considered beneficial.

\section{LIMITING DOSE TO OBSERVERS}

Because the steam generator replacement operation at Surry Unit 2 was the first of its kind, 50 or more observers were present. Inspectors from NRC Region II and personnel from NRC headquarters were present 1) to inspect the operation and ensure that it was carried out within prescribed regulations and technical specifications, and 2) to gather information that would be useful in analyzing licenses submitted for similar operations. Individuals from VEPCO who had been involved in planning the repair and personnel from other utilities that are pianning similar operations were there to observe and learn so that costs, outage time, and occupational dose can be cut significantly in the future. These persons assisted those conducting the operation, verified that engineering details were as expected and that work was done as planned, and will participate in improving the plans for otner steam generator repairs.

Although the need for observers will continue, it is likely that fewer will be present at subsequent steam generator replacements. To reduce the amount of time observers spend in radiation zones, television cameras and 
video tapes could be used or areas with lower radiation exposure rates and a reasonable view of the work could be designated observation areas.

USING THE ALARA PRINCIPLE

Maintaining occupational doses as low as is reasonably achievable (ALARA) is both a judicious and an economical practice during any extended maintenance outage, as well as during normal operations. The motivation behind the ALARA philosophy is to reduce the radiation dose to both the individual and the entire work force. In addition to protecting the workers, this approach can result in a greater availability of skilled workers for tasks involving exposure to radiation. The techniques used at Surry lin it 2 to reduce the occupational dose included mockup training, decontaminating the reactor coolant piping, using automatic welding equipment, and plasma arc cutting.

An excellent way of implementing ALARA is to track worker doses by task, occupation, employer, work location, and time in the radiation zone. This comprehensive tracking permits the analysis both of methods used to accomplish the task and of methods used to control the exposure. From the results of the analysis, we can learn to do a better job while incurring less dose. Specifically, the analysis could help us

- devise a new approach that would reduce occupational dose

- determine any need to further reduce the radiation field for similar work or work in the same location

- compare dose estimates to the dose actualiy received, to help in planning future efforts

- plan other steam generator repair operations

- pinpoint tasks that result in high occupational doses.

Containment envelopes are sometimes excellent devices for lowering occupational doses. They tend to reduce the need for local decontamination, reduce airborne activity, and restrict the spread of contamination. However, dose tracking done at Surry Unit 2 showed that in some instances 
more dose was received during the construction of the containment envelope than during the cutting or grinding operation it was intended to confine. The Surry experience indicated that the decision to construct containment envelopes should be based on experience, the contamination level involved, and consideration of ALARA principles.

The total number of people in the containment building is an ALARA concern since the intent of ALARA is to keep the dose to population groups, as well as to the individual, as low as possible. Although the large group of observers at Surry Unit 2 received some radiation dose, it is highly probable that what they learned through observation will reduce the radiation dose received during future operations by more than the amount they received during this repair effort. Planning based on the experience at Surry Unit 2 will help ensure that future steam generator repair operations are conducted according to ALARA principles, will reduce the amount of waste generated, and may even reduce the total outage time if, for example, the construction of containment envelopes is on the critical path and the number constructed is reduced.

\section{CONCLUSIONS}

Much was learned at Surry Unit 2 about the health physics problems associated with steam generator removal and replacement. The next such operation will have the advantage of using experienced personnel who have a much better understanding of the health physics concerns specific to the operation and, based on the experience at Surry Unit 2, can more easily anticipate the number of workers needed and the amount of waste generated.

Additional attention to the training of workers, especially those wno have no experience in radiation zones, is essential to ensuring their protection. The training snould be geared specifically to the job at hand and its inherent problems, and toward the various levels of worker experience.

As always, the occupational dose to workers should be kept as low as is reasonably achievable. The use of low radiation zones with in the containment area should be stressed, and, if possible, staging areas outside the containment area should be established for backup crews. The number of observers in 
radiation zones should be kept to a minimum. However, there is still a great. deal to be learned about steam generator repair oparations, and observers who have a definite need to know snould not be restricted from tne area during the operations.

Communication of the knowledge gained during the Surry Unit 2 operation is essential so that otners may learn from the experience. Information about the operation would be most effectively dispersed by those who participated in planning and conducting the removal and replacemen: of the steam generator. Allowing representatives to observe the work at Surry was an efficient means of communication with other utilities planning steam generator repairs, but more widespread distribution of first-hand knowledge is desirable. 


\section{REFERENCES}

1. Hoenes, G. R., D. A. Waite and W. D. McCormack. 1978. Radiological Assessment of Steam Generator Removal and Replacement. NUREG/CR-0199 (PNL-2656), U.S. Nuclear Regulatory Commission, Washington, D.C.*

2. Virginia Electric and Power Company. 1979. Steam Generator Repair Program for the Surry Power Station Unit No. 2 - Progress Report - No. 1, February 3 through March 31, 1979. NRC Docket Nos, 50-280 and 50-281, Washington, D.C.

3. Virginia Electric and Power Company. 1979. Steam Generator Repair Program for the Surry Power Station Unit No. 2 - Progress Report - No. 2, April 1 through May 31, 1979. NRC Docket Nos. 50-280 and 50-281, Washington, D.C.

4. Virginia Electric and Power Company. 1979. Steam Generator Repair Program for the Surry Power Station Unit No. 2 - Progress Report - No. 3, June 1 through July 31, 1979. NRC Docket Nos. 50-280 and 50-281, Washington, D.C.

5. Virginia Electric and Power Company. 1979. Steam Generator Repair Program for the Surry Power Station Unit No. 2 - Progress Report - No. 4, August 1 through September 31, 1979. NRC Docket Nos. 50-280 and 50-281, Washington, D.C.

6. Virginia Electric and Power Company. 1979. Steam Generator Repair Program for the Surry Power Station Unit No. 2 - Progress Report - No. 5, October 1 through November 30, 1979. NRC Docket Nos. 50-280 and 50-281, Washington, D.C.

7. Virginia Electric and Power Company. 1979. Steam Generator Repair Program for the Surry Power Station Unit No. 2 - Final Report (Progress Report - No. 5) for the Period February 3, 1979 through December 31, 1979. NRC Docket Numbers 50-280 and 50-281, Washington, D.C.

8. Smith, R. I., G. J. Konzek and W. E. Kennedy, Jr. 1978. Technology, Safety and Costs of Decommissioning a Reference Pressurized Water Reactor Power Station. NUREG/CR-0130, Vols. 1 and 2 and Addendum, U.S. Nuclear ReguTatory Comission, Washington, DC 20555.*

9. Florida Power and Light Company. 1980. Steam Generator Repair Report Turkey Point Units 3 and 4. NRC Docket Nos. 50-250 and 50-251, Washington, 0.C.

10. Virginia Electric and Power Company. 1978. Steam Generator Repair for the Surry Power Station Un it Numbers 1 and 2. NRC Docket Nos. 50-280 and 50-281, Washington, D.C. 
11. Kennedy, A. J. 1977. "PWR Corrosion Products: Synthesis and Significance." Babcock and Wilcox Document No. ROTPL-77-24, presented to the American Nuclear Society, November 27-December 2, 1977, San Francisco, California.

12. Ayres, J. A., ed. 1970. Decontamination of Nuclear Reactors and Equipment, Chapters $4,7,9,15,16$, and 17. The Ronald Press Co., New York.

13. Westinghouse Electric Corporation, R. J. Lutz, Jr., Ed. 1977. Design, Inspection, Operation and Maintenance Aspects of the WisSS to Maintain OccupationaT Radiation Exposures As Low As Reasonably Achievable. WCAP-88-72, Pittsburgh, Pennsylvania.

14. Cohen, P. 1969. Water Coolant Technology of Power Reactors, Chapters 8 and 9. Gordon and Breach Science Publishers, New York.

15. Consumers Power Company. 1980. Steam Generator Repair Report - Palisades Plant. NRC Docket No. 50-255, Revision 5, Washington, D.C.

16. Roberts, 0.R. 1960. "How to Estimate Piping Labor." The Petroleum Refiner 39(3):207-212.

17. Herkimer, H. 1958. Cost Manual for Piping and Mechanical Construction. Chemical Publishing, Inc., New York.

13. Peck, L. J. 1979. Occupational Radiation Exposure at Light Water Cooled Power Reactors: Annual Report, 1977. NUREG-0482, U.S. Nuclear Regulatory Commission, Washington, D.C.**

19. Ashmore, J. P., and D. Grogan. 1978. "Dose Statistics for Nuclear Fuel Cycle Workers in Canada." IAEA-SM-242/39, International Atomic Energy Agency, Vienna, Austria.

20. U.S. Nuclear Regulatory Commission, Office of Standards Development. 1979. Design, Testing and Maintenance Criteria for Normal Ventilation Exhaust Systems Air Filtration and Adsorption linits of Light-Water-Cooled Nuclear Power Plants. U.S. NRC Regulatory Guide 1.140, Rev. 1, Washington, D.C.

21. U.S. Nuclear Regulatory Comission, Office of Standards Development. 1976. Calculation of Releases of Radioactive Materials in Gaseous and Liquid Effivents from Pressurized Water Reactors (PWR-GALE Code). NUREG-0017, Washington, OC 20555.*

*Avaltable for purchase from the National Technical Information Service, Springfield, VA 22161.

**Available for purchase from the NRC/GPO Sales Program, U.S. Nuclear Regulatory Comission, Washington, DC 20555, and the National Technical Information Service, Springfield, VA 22161. 
APPENDIX A

DECONTAMINATION OF STEAM GENERATORS 
APPENDIX A

\section{DECONTAMINATION OF STEAM GENERATORS}

A decontamination process is a means of removing radioactive material deposited on surfaces of the primary coolant system of a reactor. Decontamination processes might be applied to lower the radiation exposure rates in and around the entire steam generator or to lower the exposure rates in a specific area (e.g., the channel head) of a steam generator. This discussion will focus on decontaminating a steam generator still in the primary system, although some of the techniques discussed here could also be used for a generator outside of containment.

Decontamination processes can be grouped into three categories: 1) chemical, 2) mechanical, and 3) water chemistry modification. Chemicais dissolve surface films and deposits so that they can be removed from the system. Mechanical decontamination processes use u1trasonic techniques, grinding, grit blasting, high-velocity fluids, or a combination of the last two to remove contamination. Water chemistry modification is not typicaliy thought of as a decontamination technique, but may be used as one. Forced oxidation, one such process, involves the addition of oxygen (usually in the form of hydrogen peroxide) to the system to change some of the crud from an insoluble to a more soluble form and remove it. (1)

This appendix covers the method of application, waste volumes, probable decontamination factors, and some problem areas for each of the three categories of decontamination processes.

\section{CHEMICAL DECONTAMINATION PROCESSES}

Various types of chemicals can be used to remove surface deposits and films from the primary side of a steam generator. Two methods of applying decontamination solutions to a system are to l) fill, soak, and drain, or 2) spray. Each method has advantages and disadvantages, and each requires that all traces of the solution be rinsed from the steam generator to prevent 
damage to other parts of the primary system. Electropolisning and electrochemical techniques can also be used to remove deposits.

Fill, Soak, and Drain

The fill, soak, and drain method would require flooding the entire primary side of the steam generator with decontamination solution, allowing sufficient time for the solution to remove the corrosion, and then draining the steam generator. The hot and cold legs of the steam generator would have to be blocked during tnis procedure to hold the decontamination solution in the steam generator and to prevent the solution from getting into other parts of the primary system. The results obtained with this method could be improved if the solution recirculated. The system would then be rinsed to remove all of the solution. This method allows a long time for contact between the solution and the surfaces to be decontaminated. The ecuipment to do the task is relatively simple and the process commonly performed.

The fill, soak, and drain method of applying $\vec{a}$ decontamination solution would result in a large volume of liquid waste. For a U-tube steam generator, about 26,500 1 of solution and 53,000 to 79,500 1 of rinse water would be required. For a once-through steam generator, c.pproximately twice these volumes would be necessary because of the larger volume on the primary side. (2) Several hundred curies of radioactive material would probably be removed from the steam generator; therefore, the spent decontamination solution would be highly radioactive. Handing, storing, and treating this solution could be a problem.

An alternative to the fill, soak, and drain method is one similar to the Canadian CANDECON process, which uses low-concentration solvents and ion exchange beds to remove corrosion products from the primary system. In Canada, this process is applied to the entire primary system with the fuel in place. This method of decontamination is not currently used in the United States. The solvent is not effective on the corrosion deposited in pressurized water reactors (1) (PWRs) and problems may arise if the method is applied where fuel is in place because this may be considered an unreviewed licensing action. 


\section{Spray Application}

Spray appication of a decontamination solution would require the installation of spray heads and feed piping in the channel head of the steam generator. The hot and cold legs in U-tube steam generators would probably nave to be blocked to prevent the solution from getting into the rest of the primary system. For a once-through steam generator, blocking might not be necessary. (2) Following application of the decontamination solution, rinsing would be required.

This method of applying a decontamination solution would place fresn solution on the exposed parts of the channel head. However, the tubes in both types of steam generator would not receive a thorough decontamination. Very little of the solution would get into the tubes of a U-tube steam generator, and the tubes in a once-through steam generator would not receive continuous and thorough wetting. This method is therefore best applied to only the channe1 head area of the steam generator.

Spray application would require approximately 19,000 1 of solution and as much as 190,000 to 380,0001 of rinse water, (2) a large volume to be handled by a radioactive waste treatment system. The volume of solution might be reduced by recycling the decontamination agent. The occupational dose from this method of application could be much higher than the dose from the fill, soak, and drain method since more time would be spent in the channel head installing the spray equipment. More study on the applicability of this technique is needed.

Types of Decontamination Solutions

Several types of decontamination solutions are available for use in steam generators, including phosphoric acid, AP-Citrox, and Dow NS-1. For each of these, 1) use of the solution has not yet been demonstrated on a PWR primary system, 2) a high volume of radioactive liquid waste will result, and 3) a major requirement for use would be NRC licensing of the decontamination operation and certification for resumption of operation following decontamination. 
Phosphoric acid has been used as a decontamination agent at the $H$ anford N-Reactor. (3-6) Althougn the corrosion rate on stainless steel is relatively low for short contact times, the use of uninhibited phosphoric acid on carbon stee 1 is not recommended even at room temperature. (l) If any portion of the steam generator is to be reused, phosphoric acid should not be considered as a decontamination solution because parts of the component may be damaged. The best method of application for keeping contact times short would probably be spraying.

The use of AP-Citrox is a two-step decontamination process. The first step, alkailine permanganate $(A P)$, is required in systens that contain stainless steel or have a reducing environment. Alkaline permanganate is not very corrosive to stainless steel or carbon steel. (7) Tre corrosion rate on carbon steel is about $6 \mu \mathrm{m} / \mathrm{d}$. (7) A problem of considerable concern when using AP is that any residuals may cause caustic cracking when the system is returned to operating temperatures. (7) To avoid this, the system must be thoroughly flushed to remove all traces of AP. The Citrox step of the AP-Citrox process is effective on stainiess steel onjy after the AP step has been applied. Ammonium citrate has high corrosion rates on carbon steel $(25 \mu \mathrm{m} / \mathrm{h}) .(7)$

Generally, AP-Citrox has high corrosion rates, especially on carbon steel. To minimize the effects on a system, the solutions are allowed to stay in contact with the metal surfaces for only a short period of time and inhibitors are used. Because of the high corrosion rates, decontamination factors (DFs) of up to 200 have been obtained, but in a steam generator DFs of 20 to 100 would be more likely. (2)

Since this two-step process requires rinsing between steps, between 265,000 and 568,0001 of liquid waste could be generated during this process, depending on the type of steam generator. This decontamination process requires the application of the fill, soak, and drain method.

Dow Chemical Company has developed an agent calied NS-1 for decontamination of the Dresden-1 primary system. (8) Decontamination factors of 6 to 100 were obtained in tests on a loop at Dresden-1. (8) Tris process, however, is 
not effective on PWR corrosion films. (2) If a similar process were developed for PWRs, we estimate that the volume of liquid waste would be between 79,500 and 170,0001 per steam generator.

Electropolishing

Another method of decontamination is electropolishing or electrochemical processes. These are not strictly chemical processes, but are being considered here since chemicals (usually strong acids) are used as the electrolyte. Decontamination results from the electric current used in the process. Electropolishing is actually the reverse of electroplating; a small amount of the metal and any corrosion products are removed from the surface of the component.

Two electropolisning techniques will be considered here. The first, for decontaminating the channel head, would involve filling the channel head with electrolyte, making the channel head the anode, and placing an electrode to be used as the cathode inside the channel head. Decontamination factors of up to 1000 could result on the surfaces of the channel head. If the tubes were not decontaminated, however, the toal dose rate inside the channel head might only be reduced by a factor of about 4 because of shine. (2)

The inlet and outlet legs would have to be blocked for this type of decontamination. It is likely that materials compatibility would be poor since a strong acid or base would be used as the electrolyte. (2) If the channel head were to be reused, extensive flushing would be necessary.

The tubes could be cleaned by moving a cathode into each tube. The cathode would have to be operated remotely and would require considerable time for setup. This could be extremely time-consuming, costly, and perhaps doseintensive work.

The second approach to electropolishing is using an electrobrush consisting of a cellulose sponge kept wet by a continuous feed of sulfuric acid solution. The mop is the cathode and the surface to be decontaminated is the anode. Surfaces are decontaminated by rubbing the mop over the corrosion film until the metal looks shiny, with a resulting of of 4 to 10. (2) If the first 0.6 to $0.9 \mathrm{~m}$ of the tubes were decontaminated, a DF as high as 40 could be 
attained. (2) Considerable time and occupational dose would be involved in this process. A remote technique could be used to ciean the tubes. This approach may best be applied as a means of decontaninating the tubes after the channel head and tubesheet have been cleaned.

MECHANICAL DECONTAMINATION PROCESSES

Mechanical decontamination processes could be more useful on steam generators than chemical processes because chemical decontanination might cause stress corrosion problens. (1) Several mechanical processes available are grit blasting, the use of high-velocity fluids, and fiuids with abrasives. It is unilikely that grinding, another technique, woula be used on the channel head of a steam generator because high occupational doses would result. Grinding is best applied to much smaller areas.

Grit blasting can be used on most open surfaces by driving a stream of abrasive material at high velocity against the surface to be decontaminated. The procedure must be performed in an enclosed area to prevent the escape of grit and radioactive material, and is best nandled remotely. Decontamination factors on smooth open surfaces can range between 13 and 50. (2) The technique is less effective in corners.

Grit blasting has been attempted at the Ginna and Sena plants with little success. (2) The highest decontamination factor achieved has been 1.5 . (9) Because of airborne contamination and low DFS, this technique is probably not acceptable for decontaminating steam generators.

Mechanical decontamination is generally perforned with water ${ }^{(1)}$ because water helps minimize the amount of airborne contamination and is an effective means of transferring energy into the film removal process. The resulting liquid waste requires some special treatment. Large particles are removed in a settling tank, and the waste stream is filtered to remove suspended particles. Standard treatment can then be started on the radioactive waste stream.

With either of the techniques described, great care must be taken to remove all the abrasive material and metal fragments from the primary system. 
Grit lodged in a component or valve could ruin it. A metal fragment could be picked up by the coolant flow, pass through the core, become activated, be deposited in a low-flow area, and cause a high exposure rate in that vicinity.

To avoid these types of problems, a high-pressure water jet or water laser, or steam, could be used to decontaminate surfaces and eliminate the abrasive material. This technique could lead to a DF of 10 if a portion of the tubes were cleaned. (2) The process would be time consuming and perhaps dose intensive and might not work on the tightly adherent oxide layer in stean generators.

The amount of waste generated by these decontamination techniques varies. A sand-blast unit with a water spray collar to eliminate dust could use 4.5 to $6.8 \mathrm{~kg}$ of sand per minute and about $0.03 \mathrm{l} / \mathrm{s}$ of water. (1) A high-pressure fluid with an abrasive could use $2.21 / \mathrm{s}$ of water with a lower sand loading. (1) Depending on the task and on the tenacity of the film, as much as 76001 of water and $272 \mathrm{~kg}$ of sand could be used in an hour. (1) A water jet would produce similar amounts of liquid effluents, and a steam jet somewhat less. The total volume of radioactive waste could be sizeable depending on how long it took to clean the component.

\section{DECONTAMINATION BY WATER CHEMISTRY MODIFICATION}

The purpose of this process is to change the environment in the primary system so that deposited radioactivity is released to the surrounding solution. The application of this process has produced mixed results. (1) In some cases, significant releases of crud and film have occurred, while in others there nas been little if any effect.

The following agents might be used in this decontamination process, with the DFs for each given in parentheses: hydrazine (DF 1.5 to 3), hydrogen peroxide (DF 2 to 6), hydrogen peroxide plus a chelate (DF 2 to 15), and hydrogen peroxide-hydrazine (DF 2 to 8 ). (2) All of these agents and the corrosion products released would be removed from the system on filters and ion exchange beds. 
The results of this process are uncertain and the decontamination factors may vary greatly. Although the total amount of radioactive waste generated would not be large (several hundred cubic feet of spent resin), the waste could be very radioactive since the process is best applied to the entire primary system.

OCCUPATIONAL DOSE

The radiation dose to workers from the decontamination of a steam generator can be quite variable depending on the process employed. If access to the channel head is required to set up equipment prior to the decontamination, occupational doses can be expected to be quite high. In addition, treatment and handling of the waste resulting from decontamination can cause considerable occupational dose problems, as the amounts generatec can contain from ten to several hundred curies of radioactive material.

Estimates of the occupational dose for various steam generator decontamination processes, taken from Remark, (2) are listed in Table A.1. These estimate have rather large ranges and reflect only the relative hazard to workers for each technique.

TABLE A.1. Occupational Dose Estimates for Decontamination of a Steam Generator(2) (man-rem)

Technique

Technique
Abrasive Blasting
Electropolishing
Water Chemistry Modification
Electrobrush

Spray Application of Agent

Water Jet

Steam Jet
Occupational Dose

$5-20$

$10-100$

$10-60$

$30-150$

$20-50$

$10-30$
Comments

Remote operation

Requires remote technique

Mostly from installation of spray equipment in channel head

Remote operation

Remote operation 
The decontamination that is to take place at Dresden-1 is expected to involve an occupational dose of about 550 man-rem. $(10,11)$ Between 350 and 450 man-rem will result from the installation of piping in the primary system for the circulation of the decontamination solution. Somewhat less piping would have to be installed in a steam generator, but it would be necessary to enter the channel head prior to decontamination to block off the rest of the primary system.

At the Gundremmingen nuclear power plant (a 250-MWe boiling water reactor), the channel heads of the secondary steam generators were decontaminated in $1977^{(12)}$ using an AP-Citrox process. An occupational dose of approximately 50 man-rem was involved, almost $30 \%$ of which came from the installation of plugs to isolate the steam generator from the remainder of the primary system. Approximately 15,900 l of decontamination solution were used. The total amount of Tiquid waste was not documented. The decontamination solution was solidified without concentration because the installed radioactive waste treatment system could not chemically handle the solution. (12)

At Dresden-1, a new radioactive waste treatment system has been built to handle the volume of waste expected from the decontamination. Unless similar steps are taken for a steam generator decontamination, high occupational doses could result from the treatment and handing of the waste. Factors that can affect the occupational dose from handling decontamination waste are: 1) the volume of waste, 2) the efficiency of the decontamination process (which determines the amount of radioactive material in the waste), 3) the method of handling the waste (remote or hands-on, ion exchange or evaporators, etc.), 4) the use of an old versus a new waste treatment system, 5) the use of system(s) brought in from offsite, and 6) the amount of maintenance and the type (i.e., hands-on or remote) required by the system.

Occupational dose estimates for several tasks carried out during a steam generator decontamination are listed in Table A.2. These estimates are based on a generic nuclear plant and are given only to indicate the general range of occupational doses that may be expected from these tasks. 
TABLE A.2. Occupational Dose Esimates for Tasks During a Steam Generator Decontamiration

\begin{tabular}{|c|c|c|c|}
\hline Task Description & Man-Hours & $\begin{array}{c}\text { Exposure Rate, } \\
\mathrm{R} / \mathrm{h}\end{array}$ & $\begin{array}{c}\text { Occupational Dose, } \\
\text { man-rem }\end{array}$ \\
\hline move manway covers & 8 & $0.3-5$ & 20 \\
\hline ean up manway & 16 & $0.5-10$ & 80 \\
\hline $\begin{array}{l}\text { emotely place inflatable } \\
\text { plugs in coolant inlet } \\
\text { and out let }\end{array}$ & 4 & 0.5 & 20 \\
\hline $\begin{array}{l}\text { Decontaminate channel head } \\
\text { 1) Fill channe } 1 \text { head, } \\
\text { then scrub surfaces } \\
\text { with long-handled } \\
\text { equipment }\end{array}$ & 48 & $0.5-10$ & 100 \\
\hline $\begin{array}{l}\text { 2) Use aqua-blast } \\
\text { equipment }\end{array}$ & 16 & $0.5-10$ & 30 \\
\hline lectropolish channel head & 16 & $0.2-6$ & 15 \\
\hline \multicolumn{4}{|l|}{ CONCLUUSION } \\
\hline \multicolumn{4}{|c|}{$\begin{array}{l}\text { In-place decontamination of a steam generator is a difficult procedure. } \\
\text { Experience has shown that decontamination operations using chemical solutions } \\
\text { are very complex. (1) Mechanical decontamination techniques may be somewhat } \\
\text { less complex, but may require extensive development of equipment to keep } \\
\text { occupational doses low. Before any of the methods discussed in this appendix } \\
\text { can be widely used for steam generator decontamination, their effectiveness on } \\
\text { PWR corrosion films and deposits should be demonstrated and potential problems } \\
\text { such as materials compatibility and waste handing should be assessed. } \\
\text { The limited data surveyed for this report indicate that the of that can } \\
\text { be expected without cleaning of the tubes is about } 4 \text {. Much higher DFs (per- } \\
\text { haps as high as } 40 \text { to } 50 \text { ) are possible if the first } 0.6 \text { to } 0.9 \text { m of the tubes } \\
\text { are decontaminated. Decontamination factors for } 13 c a l i z e d \text { areas may be as } \\
\text { high as } 1000 \text { for techniques such as electropolishing. }\end{array}$} \\
\hline
\end{tabular}


Materials compatibility probiems may not be overriding if the steam generator or any portion of it is not to be reused. The volume of waste will be reduced in this circumstance because less rinsing will be needed. If only a portion of the steam generator (such as the channel head) is to be reused, only that portion may need to be rinsed. However, care must be taken to prevent any chemical or abrasive decontamination agent from entering other parts of the primary system.

Several techniques might be used in a series of steps during a steam generator repair operation. For instance, one technique might be used to clean a portion of the steam generator (such as the channel head) well enough to allow work in the area at reduced exposure rates; a second might be used to clean the tubes; and a third might be applied to further clean any portions of the steam generator (such as the channel head) that are to be reused.

Whichever method or methods are chosen, extensive planning and training are essential. Materials compatibility, occupational dose, waste volumes generated, waste disposal options, waste handling capability, and nonradiological safety concerns must all be considered. 


\section{REFERENCES}

1. Perrigo, L. D., J. R. Divine, G. R. Hoenes and L. G. Faust. 1979. The Impact of Decontamination on LWR Radioactive Waste Treatment Systems. NUREG/CR-0986, PNL-3297, Pacific Northwest Laboratory, Richland, Wash ington. *

2. Remark, J.F., ed. 1979. Review of Decontamination Techniques for a Steam Generator. Babcock and Wilcox Report 78:6332-01.

3. Kratzer, W. K. 1974. N-Reactor Decontamination-1973: Final Report of Production Tests N-334 and N-301, Sup 1. United Nuclear Report UNI-176, Richland, Washington.

4. Kratzer, W. K. 1975. Final Report, Production Test N-383, 1975 N-Reactor Internal Decontamination. United NucTear Report UNI-355-A, Richland, Washington.

5. Kratzer, W. K. 1978. Final Report, Product ion Test N-426, 1977 N-Reactor Internal Decontamination. United Nuclear Report UNI-759C, Richtand, Washington.

6. Kratzer, W. K. 1978. Final Report, Production Test N-442, 1978 N-Reactor Internal Decontamination. United Nuclear Report UNI-1018C, Richland, Washington.

7. Ayres, J. A., ed. 1970. Decontamination of Nuclear Reactors and Equipment. The Ronald Press Co., New York.

8. Dow Chemical Company. 1977. Technical Study for the Chemical Cleaning of Oresden $\rightarrow$. Report No. DNS-01-016, Volumes 1-8, Midlands, Michigan.

9. Remark, J.F., and A. D. Miller. 1979. "Review of Plant Decontamination Methods." In: Decontamination and Decommissioning of Nuclear Facilities, ed. M. M. Osterhout, pp. 33-45, Proceedings of the American Nuctear Society Topical Meeting in Sun Valley, Idaho. Plenum Press, New York.

10. Dow Chemical Company. No date. Oresden Unit-1 Chemical Cleaning Licensing Update. Commonwealth Edison Company, Dow Chemical Company, Report No. DNS NS-Dl-020, U.S. NRC Docket No. 50-10, Washington, D.C.

11. Catalytic, Inc. 1977. "Man-Rem Estimates for the Oresden-1 Chemical Cleaning." Philadelphia, Pennsylvania.

12. Eickelpasch, N., and M. Lasch. 1979. "In Situ Decontamination of Parts of the Primary Loops at the Gundremmingen Nuclear Power Plant." In: Decontamination and Decommissioning of Nuclear Facilities, ed. M. M. Osterhout, pp. 329-336, Proceedings of the American Nuclear Society Topical Meeting in Sun Valley, Idaho. Plenum Press, New York.

*Available for purchase from the NRC/GPO Sales Program, U.S. Nuclear Regulatory Commission, Washington, $O C$ 20555, and the National Technical Information Service, Springfield, VA 22161. 
APPENDIX B

DI SPOSAL OF STEAM GENERATORS 
APPENDIX B

\section{DISPOSAL OF STEAM GENERATORS}

Steam generator lower assemblies, when removed, represent the largest source of radioactive waste to be disposed of from repair operations. Data gatinered at Turkey Point ${ }^{(1)}$ and data presented in NUREG-0395 (2) indicate that each lower assembly contains between 400 and 1000 curies of radioactive material. The amount of external contamination on the steam generators is less than the limit for permissible surface contamination as outlined in Regulatory Guide 1.85. (3) The radionuclides that contribute most of the radiation dose are ${ }^{58} \mathrm{Co}$ and ${ }^{50} \mathrm{Co}$.

DI SPOSAL OPTIONS

Options for the disposal of old steam generators include but are not limited to

- long-term onsite storage

- interim onsite storage

- immediate cut-up and shipment

(a) with no decontamination

(b) with decontamination

- shipment intact.

Each of these options will be addressed oriefly in the following discussion. In all cases, when the steam generator lower assemblies are removed from containment, they are sealed to prevent the release of radioactive material. Long-Term Onsite Storage

A temporary onsite facility can be constructed for the storage of the lower assemblies until shipment to a licensed land-burial site can be arranged, the plant is decommissioned, or sufficient time has passed for the radioactivity to decay to levels that would make cut-up and shipment easier. 
Since the steam generators are sealed prior to removal from containment, the primary radiological problem associated with onsite storage is direct radiation. Snielding can be provided to ensure acceptable exposure rates outside the storage facility.

Although total enclosure of the sealed steam generators may not be required, it might be advisable to provide it. A complete enclosure would reduce the chance of anyone tampering with the steam generators and decrease the need for security guards. A means of checking the integrity of the steam generator seals should be provided, either through in-place monitoring equipment or through ports provided for periodic surveys.

A structure that does not fully enclose the stored steam generators will require precautionary measures to ensure their integrity, such as fencing and locking or guarding the perimeter; maintaining the steam generator shells (painting them to prevent rust); monitoring the seals to ensure no loss of integrity; providing drains with radiation monitors for rain water; and doing smear tests to ensure that external contamination remains below the level designated in Regulatory Guide 1.86. (3) This list is by no means exhaustive. All measures necessary to prevent the release of radioactive material to the environs and any intrusion into the storage area ty people or animals should be taken.

The radioactive material with in the steam generators is immobile. Therefore, if seal integrity is lost, a release to the environment is unlikely. Nevertheless, a surveiliance program is necessary and should include visual inspections of the lower assemblies, radiation surveys of the area, and swipes of the welds sealing the openings, depending on the design of the storage facility.

Interim Onsite Storage

Onsite storage may be chosen initially in the expectation that several options for disposal may be available in the future. It might at some time become a viable and competitive option to ship steam generators intact to an offsite disposal facility. Moreover, radioactive fecay during long-term 
storage will reduce activity levels to less than $1 \%$ of those expected when the steam generators are first removed. These reduced levels will allow the steam generators to be segmented with a minimum of radiation exposure.

Immediate Cut-Up and Shipment

At present, lower assemblies can be disposed of at a licensed land-burial site if they have been segmented prior to shipment. Currently, rail or truck transport or a combination of the two are acceptable alternatives for shipment. Rail can be used to transport the channel head and tubesheets, and truck to transport other pieces.

The lower assemblies can be cut into segments suitably sized for the chosen method of shipment. Since the expected radioactive content of the lower assemblies is at most $1000 \mathrm{C} i$ and the weight of an assembly is over $18 \times 10^{4} \mathrm{~kg}$, the cut-up sections can be packaged tightly in strong packages and shipped as low specific activity (LSA) material. If truck transport is used instead of rail, a larger number of packages would be required to accommodate the lower load limit.

Cut-up operations on the steam generators snould be performed in enclosure envelopes to minimize the spread of airborne activity. The enclosures should be provided with a HEPA filtration system to reduce any potential releases to the environment and should be designed to allow the use of remote-cutting techniques to reduce personnel dose. Temporary shielding should also be availasle to further reduce personnel radiation dose.

Shipment Intact

The only means of shipping steam generator lower assemblies intact over any appreciable distance is via barge. This method involves the least amount of handling onsite. At the present time, nowever, the capability of some licensed burial facilities to receive a large shipment of waste such as a steam generator is questionable because of restrictions placed on the burial operations by the states in which they are located. This may be an option, however, for sites located on major rivers or in coastal regions. 


\section{RADIATION EXPOSURE ESTIMATES}

The radiation doses to workers from various operations during steam generator disposal are presented in Table B.l. These operations were applied to the appropriate disposal options, and the resultant man-rem estimates are listed in Table B.2. The man-rem estimates should not be taken at face value, but rather used as a guide for the various options listed.

If steam generators are cut up for disposal, a significant benefit would be derived from short-term storage of the components. Within 5 years of the steam generators' removal, the exposure rate would be reduced to $40 \%$ of the initial value. At 10 and 15 years, the exposure rate would be reduced to $20 \%$ and $10 \%$, respectively, of the initial value.

Once the steam generators are removed, they can be much more easily decontaminated. The decontamination process can result in significant man-rem savings during the segmenting process.

Tabie B. 3 shows a comparison of the man-rem exsosures calculated in this section with those calculated by Florida Power and Light, (1) Consumers Power, (4) and VEPCO. (5)

\section{RADIOACTIVE EFFLUENTS}

The presence and amount of effluents will vary with the disposal option chosen. If onsite long-term storage is chosen, no radioactive material will be released. If, at any time, the steam generators are shipped intact to another location, there will be no release. For other options, the amount of radiaoctive material released will depend on the holding time and the contamination level. Table B.4 lists the potential airborre effluents associated with various disposal options. (we assume that there wi' be no liquid effluent. The only option that would lead to a waterborne release is cut-up of the generator, combined with chemical decontamination. In this case, however, we assume that all contaminated liquid would be solidified, packaged, and shipped to a disposal site.) 
The following calculations were used to estimate the airborne release from the immediate cut-up of steam generators, with no chemical decontamination. Other airborne releases are fractions of those listed here.

Cutting the U-tubes for packaging: assuming a cut with a $0.95-\mathrm{cm}$ kerf, 3400 tubes of 21-min diameter, and $68 \mu \mathrm{Ci} / \mathrm{cm}^{2}$ on the interior of the tubes, then

$3400 \times 2.1 \mathrm{~cm} \times \pi \times 0.95 \mathrm{~cm}=2.1 \times 10^{4} \mathrm{~cm}^{2}$

of material vaporized per cut of the tube bundle, and

$2.1 \times 10^{4} \mathrm{~cm}^{2} \times 68 \mu \mathrm{Ci} / \mathrm{cm}^{2}=1.4 \times 10^{6}{ }_{\mu} \mathrm{Ci}$ released.

It is likely that two cuts will be made for easier packaging. With a decontamination factor $(6)$ of $10^{2}$ (one HEPA filter preceded by a demister), the release to the atmosphere would be $2.8 \times 10^{4}{ }_{\mu \mathrm{C} i}$.

Cutting out the channel head and tubesheet: assuming that one cut with a 0.95-cm kerf is made around the circumference of the channel head (220-cm inside diameter), and assuming $68 \mu \mathrm{Ci} / \mathrm{cm}^{2}$ on the interior surface, then

$220 \mathrm{~cm} \times \pi \times 0.95 \mathrm{~cm}=660 \mathrm{~cm}^{2}$ of material vaporized, and $660 \mathrm{~cm}^{2} \times 68 \mu \mathrm{Ci} / \mathrm{cm}^{2}=4.5 \times 10^{4} \mu \mathrm{C} i$ released.

With a decontamination factor ${ }^{(6)}$ of $10^{2}$ (one HEPA filter preceded by a demister), the release to the atmosphere would be $450{ }_{\mu} \mathrm{Ci}$.

The release involved in separating the tubes from the tubesheet is the same as that calculated for cutting the tubes, with only one cut necessary. The release is therefore $1.4 \times 10^{4} u C i$. The total release for the steps outlined is then $4.2 \times 10^{-2} \mathrm{Ci}$.

\section{CONCLUSION}

Currently, the options for steam generator disposal under serious consideration are onsite long-term storage and immediate cut-up and shipment to a licensed disposal site. Of these two, lang-term storage offers the greatest man-rem savings but may also be the option least desirabie to legisiators and the general public. Immediate cut-up and shipment is costly with respect to radiation dose and from a purely economic standpoint. If chemical decontamination is used prior to cut-up, a significant savings in radiation dose may 
result. This option, however, with its associated waste-handling problems and requirements for the treatment of liquid radioactive waste, ${ }^{(7)}$ could add a significant additional cost to an already expensive procedure (see Appendix A). Especially from the standpoint of occupational dose, temporary onsite storage of steam generators results in a significant savings.

Shipment of steam generators to a licensed commercial burial facility may be feasibile from a technical viewpoint; however, because of restrictions placed on some burial sites by the states in which they are located, this option may not be feasible. Disposing of steam generators by intact shipment has the same occupational dose benefits as long-tern onsite storage and the additional benefit of not requiring capital investment in a storage facility. 
TABLE B.1. Exposure, Time, and Man-Rem Estimates for Various 0perations During Disposal of Steam Generators

\begin{tabular}{|c|c|c|c|c|}
\hline Operation & $\begin{array}{c}\text { Exposure Rate, } \\
\mathrm{R} / \mathrm{h}(\mathrm{a}) \\
\end{array}$ & $\begin{array}{l}\text { Time Estimate, } \\
\text { man-h } \\
\end{array}$ & $\begin{array}{r}\text { Do } \\
\text { man- }\end{array}$ & $\begin{array}{l}\text { ose, } \\
\text {-rem }(a)\end{array}$ \\
\hline $\begin{array}{l}\text { Move steam generator to storage } \\
\text { or cut-up facility, deposit, } \\
\text { and seal facility. }\end{array}$ & 0.03 & 80 & 2. & .4 \\
\hline $\begin{array}{l}\text { Monitor steam generator in } \\
\text { sealed storage facility for } \\
\text { about } 30 \text { years. }\end{array}$ & 0.005 & $50 / \mathrm{yr}$ & 7. & .5 \\
\hline $\begin{array}{l}\text { Move steam generator to barge, } \\
\text { deposit on barge, and ready for } \\
\text { departure (no storage period). }\end{array}$ & 0.03 & 80 & 2. & .4 \\
\hline $\begin{array}{l}\text { Decontaminate exterior of steam } \\
\text { generator and remove insulation. }\end{array}$ & $--(0.2)$ & 50 & 10 & \\
\hline $\begin{array}{l}\text { Connect piping and equipment } \\
\text { for decontamination of interior } \\
\text { of steam generator } U \text {-tubes. }\end{array}$ & $--(0.5)$ & $50(b)$ & -- & $(12)$ \\
\hline $\begin{array}{l}\text { Decontaminate interior of steam } \\
\text { generator. Treat radwaste with } \\
\text { mobile system and package waste } \\
\text { for shipment. (c) }\end{array}$ & $--(0.1)$ & 100 & $-\cdots$ & $(10)$ \\
\hline Disconnect installed piping. & $--(0.1)$ & 20 & $-\cdots$ & (2) \\
\hline $\begin{array}{l}\text { Segment shell of steam genera- } \\
\text { tor. Package for shipment. }\end{array}$ & $0.2(0.1)$ & 500 & 100 & $(50)$ \\
\hline $\begin{array}{l}\text { Cut out channel head and tube- } \\
\text { sheets. Package for shipment. }\end{array}$ & $3 \quad(0.6)$ & 65 & 195 & $(40)$ \\
\hline Cut out U-tubes and package. & $1 \quad(0.5)$ & 250 & 250 & $(125)$ \\
\hline $\begin{array}{l}\text { Clean up area within cut-up } \\
\text { facility. }\end{array}$ & $0.5(0.25)$ & 50 & 25 & (13) \\
\hline
\end{tabular}

(a) Numbers in parentheses apply to a disposal option including chemical decontamination of steam generator.

(b) About 24 of the 50 man-h will be spent in radiation zone where welders will connect flange.

(c) Most of this operation will be done remotely. Some nands-on work may, however, be required. 
TABLE B.2. Comparison of Man-Rem Estimates for Stean Generator Disposal ATternatives

\begin{tabular}{|c|c|}
\hline Option & $\begin{array}{l}\text { Approximate Man } \\
\text { per Steam Gener }\end{array}$ \\
\hline Long-term storage with cut-up and shipment & 16 \\
\hline Long-term storage with intact shipment & 10 \\
\hline $\begin{aligned} \text { Shorter-term storage with cut-up } & - \text { at } 5 \mathrm{yr} \\
& - \text { at } 15 \mathrm{yr}\end{aligned}$ & $\begin{array}{r}230 \\
60\end{array}$ \\
\hline $\begin{array}{l}\text { Immediate cut-up and shipment by } \\
\text { rail/truck - no decontamination }\end{array}$ & 580 \\
\hline $\begin{array}{l}\text { Immediate cut-up and shipment by } \\
\text { rail/truck - with chemical decontamination }\end{array}$ & 270 \\
\hline Immediate intact shipment (a) & 2.4 \\
\hline
\end{tabular}

(a) Estimates for short-term storage followed by intact shipment would be only slightiy larger than this, perhaps 5 man-rem.

TABLE B.3. Comparison of Estimated 0ccupational Doses for Steam Generator Disposal Alternatives

\begin{tabular}{|c|c|c|c|c|}
\hline Option & This Report & $\mathrm{FPL}(1)$ & VEPCO (5) & Consumers (4) \\
\hline $\begin{array}{l}\text { Long-term storage with } \\
\text { cut-up and shipment }\end{array}$ & 50 & $26-27$ & & \\
\hline $\begin{array}{l}\text { Long-tern storage with } \\
\text { intact shipment }\end{array}$ & 30 & $26-27$ & 80 & $5-10$ \\
\hline $\begin{array}{l}\text { Shorter-term storage } \\
\text { with cut-up }- \text { at } 5 \mathrm{yr} \\
- \text { at } 15 \mathrm{yr}\end{array}$ & $\begin{array}{l}690 \\
180\end{array}$ & -- & & \\
\hline $\begin{array}{l}\text { Immediate cut-up and } \\
\text { shipment by rail/truck } \\
\text { - no decontamination }\end{array}$ & 1700 & $750-1525$ & $1000-2000$ & $575-750$ \\
\hline $\begin{array}{l}\text { Immediate cut-up and } \\
\text { shipment by rail/truck } \\
\text { - with chemical } \\
\text { decontamination }\end{array}$ & 810 & $125-575$ & & \\
\hline $\begin{array}{l}\text { Immediate intact } \\
\text { shipment }\end{array}$ & 7 & $27-28$ & 200 & $1-5$ \\
\hline
\end{tabular}


TABLE B.4. Comparison of Airborne Effluents for Steam Generator Disposal Alternatives

$\begin{array}{lc}\text { Long-term storage with cut-up and shipment } & \begin{array}{c}\text { Approximate Airborne } \\ \text { Release, ci }\end{array} \\ \begin{array}{l}\text { Long-term storage with intact shipment } \\ \text { Shorter-term storage with cut-up - at } 5 \text { yr } \\ \text { Negligible }\end{array} & 0.005 \\ \text { Immediate cut-up and shipment by } 15 \text { yr } & 0.015 \\ \text { rail/truck - no decontamination } & 0.042 \\ \text { Immediate cut-up and shipment by } & 0.010 \\ \text { rail/truck - with chemical decontanination } & \text { Negligibie (a) } \\ \text { Immediate intact shipment (a) } & \\ \text { - Since the steam generator will be sealed before it is } \\ \text { removed from containment, no release of radioactive } \\ \text { material is expected during these operations. }\end{array}$




\section{REFERENCES}

1. Florida Power and Light Company. 1980. Steam Generator Repair Report Turkey Point Units 3 and 4. NRC Docket Nos. 50-250 and 50-251, Washington, D.C.

2. Smith, R. I., G. J. Konzek and W. E. Kennedy, Jr. 1978. Technology, Safety and Costs of Decommissioning a Reference Pressurized Water Reactor Power Station. NUREG/CR-0130, Vols. 1 and 2 and Addendum, U.S. Nuclear Regulatory Commission, Washington, DC 20555.*

3. U.S. Atomic Energy Commission, Directorate of Regulatory Standards. 1974. Termination of Operating Licenses for Nuclear Reactors. Regulatory Guide 1.86, Washington, D.C.

4. Consumers Power Company. 1980. Steam Generator Repair Report - Palisades Plant. NRC Docket No. 50-255, Revision 5, Washington, D.C.

5. Virginia Electric and Power Company. 1978. Steam Generator Repair for the Surry Power Station Unit Numbers 1 and 2. NRC Docket Nos. 50-280 and 50-281, Washington, D.C.

6. U.S. Nuclear Regulatory Commission, Office of Standards Development. 1979. Design, Testing and Maintenance Criteria for Normal Ventilation Exhaust Systems Air Fittration and Adsorption Units of Light-Water-Cooled Nuclear Power Plants. U.S. NRC Regulatory Guide 1.140, Rev. I, Washington, D.C.

7. Perrigo, L. D., J. R. Divine, G. R. Hoenes and L. G. Faust. 1979. The Impact of Decontamination on LWR Radioactive Waste Treatment Systems. NUREG/CR-0986, PNL-3297, PaCific Northwest Laboratory, Richland, Washington. $\star \star *$

*Available for purchase from the National Technical Information Service, Springfie]d, VA 22161.

**Available for purchase from the NRC/GPO Sales Program, U.S. Nuclear Regulatory Commission, Washington, $D C$ 20555, and the National Technical Information Service, Springfield, VA 22161. 


\section{APPENDIX C}

IN-PLACE RETUBING OF STEAM GENERATORS 


\section{APPENOIX C}

\section{IN-PLACE RETUBING OF STEAM GENERATORS}

An alternative to removing and replacing a steam generator, suggested by Westinghouse Nuclear Energy Systems, $(1)$ is to retube the generator while it remains in the containment building. At present, no application has been made to NRC to use this technique as a remedy for steam generator problems. However, this or similar techniques may be used in the future. In this appendix, the occupational dose and radioactive effluents from stean generator retubing are estimated.

\section{OCCUPATIONAL DOSE ESTIMATES}

Assessing potential occupational doses for in-place retubing involves three tasks: 1) identifying maintenance activities, 2) determining exposure rates, and 3 ) estimating man-hour requirements.

The maintenance activities listed here are based on the description of stearn generator retubing in WCAP-9398. (1) This document describes briefly a machine called the $R / \theta$ that performs many tasks inside the channel head, where exposure rates are high, including: machining tube welds, tack rolling, and welding new tubes in place.

Exposure rates have been taken from NUREG-0395. (2) For activities involving various exposure rates for a work crew, an average rate for the activity was developed based on the estimated time spent in each exposure zone. We assumed that exposure rates would be at the high end of the range given in NUREG-0395, thereby assuring that we are not underestimating the potential risk to workers. The purpose of decontamination is to reduce exposure rates in the channel head area. Our assumption is that the effective decontamination factor in the channel head is between 4 and 5 (i.e., the exposure rate is reduced by a factor of 4 to 5). Much of the postdecontamination exposure rate is due to shine from the tubes. Once the tubes have been removed from the tubesheet, the decontamination factor is assumed to pe approximately 100. 
Man-hour estimates for each activity, as well as a listing of the personnel involved, were developed based on prior experience and on standard estimating techniques. $(3,4)$ The estimates represent man-hours of work performed in radiation zones. Since we are not entirely familiar with the operation of the $R \theta$ machine, our estimates for its operation are best guesses of the amount of time needed to insta17, maintain, and adjust tine machine.

The product of the exposure rate $(R / h)$ and the man-hours needed for each maintenance activity, times a conversion factor ( $R$ to rem), yielded the activity dose (man-rem). The individual activity doses were then sumined to obtain the tota? occupational dose for the retubing.

The maintenance activities involved in the preparation for in-place retubing of a steam generator are listed in Table C.l. For each step of these procedures, the table also shows the exposure rate irvolved, which workers perform the job, the man-hours needed, and the potential cccupational dose for that activity. The total occupational doses estimated for each phase of the retubing operation on a single steam generator are listed below:

$\begin{array}{lc}\text { Activity } & \text { Man-rem } \\ \text { Installation and preparation } & 210 \\ \text { Decontamination } & 800 \\ \text { R日 machine operation } & 850 \\ \text { Steam drum/manway removal } & 28 \\ \text { Tube bundle removal } & 9.2 \\ \text { Tube stub pulling } & 140 \\ \text { Tubesheet refurbishment } & 33 \\ \text { Tube cutting } & 2.7 \\ \text { Steam generator reassembiy } & 140 \\ \text { Upper shell closure } & 29 \\ \text { Nondestructive examination } & 11 \\ \text { Postweld heat treatment } & 7.1 \\ \text { Cleanup } & -6.3 \\ \text { Total } & \sim 2300\end{array}$


All of the estimates given in this section are for a generic case. Occupational dose estimates can vary widely from plant to plant because engineering approaches to the same problem may differ and radiation exposure rates may also differ. In this report, we have attempted to estimate an upper bound for the types of occupational doses that might be expected during steam generator retubing. With prudent engineering controls and administrative techniques, the occupational doses actually encountered will be less than those given here.

\section{ESTIMATED RELEASES}

Contamination levels in and around steam generators after several years of operation were deternined based on information contained in NUREG-0395, (2) NRC Dockets 50-250 and 50-251, (5) Babcock and Wi icox Document Number RDTPL-77-24, (6) Ayres, (7) and westinghouse Document Number WCAP-38-72.(8) Table 10 in the main text (p. 39) lists the gross contamination in the reactor piping and steam generator systems, $(2,5)$ and Table 11 gives a breakdown of contamination ievels by radionuclide for a steam generator channel nead. (5) Airborne Releases

The primary airborne releases of radionuclides during stean generator retubing would be due to: 1) cutting the channel head for the installation of manways, 2) cutting the tubes at the tubesheet for removal, 3) segmenting the tubes for packaging and disposal, and 4) cutting other steam generator system piping. Containment envelopes would be used for cuts on the channel head and the tubes. These containment envelopes have a high-efficiency particulate air (HEPA) filter in their ventilation system and would be exhausted through the plant ventilation system. For other cutting operations, no containment envelopes would be required. For our calculations, we assumed that all HEPA filters would be preceeded by a demister, which is necessary to retain filter integrity. Cutting the steam generator at the transition cone and the internal wrapper would not contribute significantly to airborne releases because the contamination levels on the secondary side of the steam generator are several orders of magnitude below those on the primary side. 
Airborne releases resulting from tube cutting were calculated as follows:

1. 3400 cuts (6800 hot and cold legs) with a $0.95-\mathrm{cm}$ kerf are made on the 21-mm tubes.

2. $3400 \times 0.95 \times 2.1 \pi=2.1 \times 10^{4} \mathrm{~cm}^{2}$ of material vaporized.

3. The contamination level on the interior of the tubes varies depending on the location of the cut. Near the tubesheet, the contamination level may be as high as $140 \mu \mathrm{Ci} / \mathrm{cm}^{2}$; at ather locations, the contamination level may be $8.2 \mu \mathrm{Ci} / \mathrm{cm}^{2}$.

4. Assume one cut near the tubesheet and two cuts at other locations to segment the tubes for shipment.

$4.2 \times 10^{4} \mathrm{~cm}^{2} \times 140 \mu \mathrm{Ci} / \mathrm{cm}^{2}=5.9 \times 10^{6}{ }_{\mu C i}$ released

$2 \times 4.2 \times 10^{4} \mathrm{~cm}^{2} \times 8.2 \mu \mathrm{Ci} / \mathrm{cm}^{2}=6.9 \times 10^{5} \mu \mathrm{Ci}$ released

Total released from tube cutting $=6.6 \times 10^{6}{ }_{\mu} \mathrm{c} i$.

5. With a decontamination factor ${ }^{(9)}$ of $10^{4}$ (two HEPA filters preceeded by demisters), release to the atmosphere is $660 \mu \mathrm{Ci}$ per steam generator.

The airborne releases from other cuts were calculated in a similar manner. The following is a list of the airborne releases in $\mu \mathrm{C} i$ expected during steam generator retubing.

\begin{tabular}{lc} 
Cutting channel head for manways & 3.3 \\
(two 81 -cm-diameter access holes) & \\
Cutting other 1 ines & 64 \\
Cutting tubes & 660 \\
\hline & \\
Total from cutting operations & 730
\end{tabular}

A few other operations could result in some airborne releases, but if the operations were conducted carefully, these releases would not significantly affect the total. Some of these operations are: tuse stub pulling, channel head decontamination, and welding of new tubes to the tubesheet. Airborne contamination for the first two tasks could be minimized by using water to reduce the suspension of radioactive material. Welding operations on the 
tubesheet should result in only minimal airborne contamination since the tubesheet would be decontaminated.

Assuming three steam generators per reactor unit, the total airborne releases for retubing would be approximately $2100 \mu \mathrm{Ci}$ per unit. The radionuclide distribution would be very similar to that listed in Table 11 of the main text.

Waterborne Releases

Liquid effluents from steam generator retubing would probably be similar to effluents from steam generator removal and replacement. The primary sources of 1 iquid effluents would be the release of reactor coolant water and the discharge of laundry waste water. The calculation of these releases is described on pages 36-37, and the amounts of the releases are 1 isted in Tables 14 and 16 of the main text. In addition to these effluents, some iiquid would be generated during the decontamination of the channel head and tubesheet, with the amount depending on the decontamination process chosen. Between 2000 and 250,000 I of liquid might have to be processed for shipment and disposal (see Appendix A). The processing could be by ion exchange, evaporation and solidification, or solidification only.

Solid Wastes

The solid wastes generated during retubing operations would include the plastic (or other material) and wood or metal used to construct containment envelopes, HEPA filters, some disposable clothing, solidified decontamination effiuent or ion exchange resin, insulation from the steam generator, and tube bundles. In addition, some rags and paper, some temporary shielding material, and any strippable coatings that become contaminated would be disposed of as waste. This material, with the exception of the tubes and decontamination effluent, would amount to approximtely $1000 \mathrm{~m}^{3}$ of low-level waste per steam generator.

The contaminated tubes removed from the steam generator would be segmented and packaged in three packages with a volume of 8.5 to $15 \mathrm{~m}^{3}$ each. The tube stubs that are pulled from the tubesheet after the tubes are removed would de packed into about 20 drums with a volume of $0.21 \mathrm{~m}^{3}$ each. 
The volume of the solidified effluent from the channel head and tubesheet decontamination would depend on the decontamination process used. The amount of 1 iquid generated would be between 2000 and 250,000 1. If treated by ion exchange, betweeen 3 and $8.5 \mathrm{~m}^{3}$ of resin would be used. If evaporation is used, about 5 to $250 \mathrm{~m}^{3}$ of solidified waste would result. If the liquid is solidified without treatment, 30 to $400 \mathrm{~m}^{3}$ of waste would result assuming that concrete is used as the solidification agent.

\section{CONCLUSION}

Steam generator retubing may be a viable alternative to removal and replacement in some instances. For example, if a steam generator will not fit through the equipment hatch and the utjlity does not wisn to cut a nole in the containment building, retubing may be the best method of repairing the steam generator. All options for handling a corroded steam generator should be considered and that option chosen which is economical and practical from a radiological standpoint.

A comparison of our generic occupational dose estinates and those made by westinghouse shows that the generic estimates are about one order of magnitude higher. Westinghouse estimates that 150 to 200 marl-rem would be involved in retubing a steam generator. The generic analysis gives a total occupational dose of about 2300 man-rem per steam generator. This difference occurs because the generic estimate uses radiation exposure rates that are significantly nigher than those assumed by westinghouse. We used a conservative approach when choosing exposure rates. In most cases, this approach results in an overestimate of the occupational dose that would actually be received. The time esimates in the generic study are based on information available in WCAP-9398 (1) and on some experience with specific tasks described in that document. Westinghouse estimates are based on a muzh more refined knowledge of the retuoing operations, which they developed.

A specific problem in the formulation of our analys is was the operation of the $R \theta$ machine. WCAP-9398 (1) did not contain enough information so that we could accurately estimate the number and location of the people operating 
the machine, and the exposure rates for its operation. If the Re machine works as it has been designed to, it could significantly lower the occupational dose to workers. It would probably be the best mechanism for implementing the ALARA principle during the entire retubing operation. If, however, significant maintenance or operational problems were to arise with the Re machine during retubing, the occupational dose to workers would probably increase during the correction of those problems.

The following conclusions are based on our review of WCAP-9398(1) and on our independent assessment of in-place steam generator retubing.

1. Before this technique can be used, channel head and tudesheet decontamination must be demonstrated to better quantify decontamination factors, the amount and type of wastes generated, techniques for handling wastes, occupational doses, materials compatibility, and other factors that could affect the decontamination operations or the reactor system.

2. Significant time should be spent testing the Ro machine to ensure that its operation during a retubing will be trouble free. Extensive training of crews is necessary, including practice on mockups, before this machine is used in an operating plant.

3. Finaliy, a retubing operation should be performed to snow that it can be done economically and without resulting in excessive occupational dose or radioactive wastes. 
IABLE C.1. Steam Generator In-P lace Retubing

\begin{tabular}{|c|c|c|c|c|c|}
\hline Phase & Event Description & $\begin{array}{l}\text { Exposure Rate, } \\
\text { R/n }\end{array}$ & Personnel Involved & $\begin{array}{l}\text { Event Duration, } \\
\text { man-h }\end{array}$ & $\begin{array}{l}\text { Dose, } \\
\text { man-rem }\end{array}$ \\
\hline \multirow[t]{9}{*}{$\begin{array}{l}\text { Installation and } \\
\text { Preparation }\end{array}$} & $\begin{array}{l}\text { Install scaffolding around secondary side to } \\
\text { establish work platform. }\end{array}$ & 0.2 & Carpenters & 96 & 19 \\
\hline & $\begin{array}{l}\text { Erect scaffolding around RCS and RCR piping. Wrap } \\
\text { piping with several layers of lead sheet. }\end{array}$ & o. & -aborers & 144 & 72 \\
\hline & $\begin{array}{l}\text { Erect staging ared around channel head to service } \\
\text { manways. }\end{array}$ & Э. & Carpenters & 96 & 19 \\
\hline & Erect staging for removing steam line. & 0.1 & Carpenters & 24 & 2.4 \\
\hline & $\begin{array}{l}\text { Erect work platform around refueling canal for } \\
\text { cutting of old tube bundle, wrapper, etc. }\end{array}$ & 7.05 & Carpenters & 48 & 2.4 \\
\hline & $\begin{array}{l}\text { Erect jib crane on operating deck to service steam } \\
\text { generatar cell. Erect jib crane within greenhouse } \\
\text { to service fuel canal. Erect two jib tranes } \\
\text { to service channel hedd and shell access openings. }\end{array}$ & $9 "$ & .aborers & 96 & 19 \\
\hline & $\begin{array}{l}\text { Build supporting structure and lay up lead shielding } \\
\text { against outer shell of vessel around access openings. }\end{array}$ & i). 5 & Ironworkers & 64 & 32 \\
\hline & $\begin{array}{l}\text { Erect greenhouse over steam generator cell, over } \\
\text { refueling canal work site, and arqund and over } \\
\text { staging area around channel head. (a) }\end{array}$ & 0.1 & Sarpenters & 258 & 29 \\
\hline & $\begin{array}{l}\text { Provide fresh air cupgly and contzminated exhoust jitive } \\
\text { connected to purge system for each greenhouse } \\
\text { enclosure. }\end{array}$ & $\overline{0} \cdot \overline{0} 5$ & $\begin{array}{l}\text { Sheetmetal workers } \\
\text { Electricians }\end{array}$ & 240 & 12 \\
\hline \multirow[t]{4}{*}{ Decontamination } & Remove marway covers; decontaminate and store. & 10 & Laborers & 8 & 80 \\
\hline & Install aqua blast system to clean channel head. & $?$ & Laborers & 24 & 480 \\
\hline & Install shielding plugs in primary inlet and out let. & 20 & Laborers & 8 & 160 \\
\hline & Decontaminate channel head. & 5 & Laborers & 16 & 80 \\
\hline
\end{tabular}

(a) Plastic sheet covering shall be reinforced fireproof fabric walkways covered for protection against contamination. 
TABLE C.1. (Contd)

R/e Machine

Steam Drum/Manway Remova I

\section{_._._._. Event Description \\ Install R/O machines in each 5 /de of channel head. \\ Install and tie in local control panel, set up}

ancillary power supplies, tie in complete video

and computer control netwark.

Locate and map position of tubes on primary side of tubesheet.

Remove tube-to-tubesheet lds.

Remove tube guides from newly installed tubes.

Position tube in tubesheet and tackroli.

Perform flush tube-to-tubesheet weld.

Remove steam line.

Remove miscellaneaus smali piping and instrument lines.

Cut upper shell assembly using track-mounted machine tool.

Raise upper steam drum with polar gantry crame and set aside.

Remove feedwater ring.

Cut steam generator wrapper.

Cut two access holes through lower steam generator shell.

Install lead glass shielded covers over access holes.
Exposure Rate, $R / h$

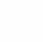

Re operators

Event Duration, man-h.

160

Dose,

800

0.1

0.1

0.1

0.1

0.1

0.05

0.05

0.05

0.05

operators

0.02

0.05

0.1

0.05
5.4

109

11

2.7

io

21

6.4

$B$

7.7

1

0.16

1.6

1.4

1,6 
TABLE C.1. (Contd)

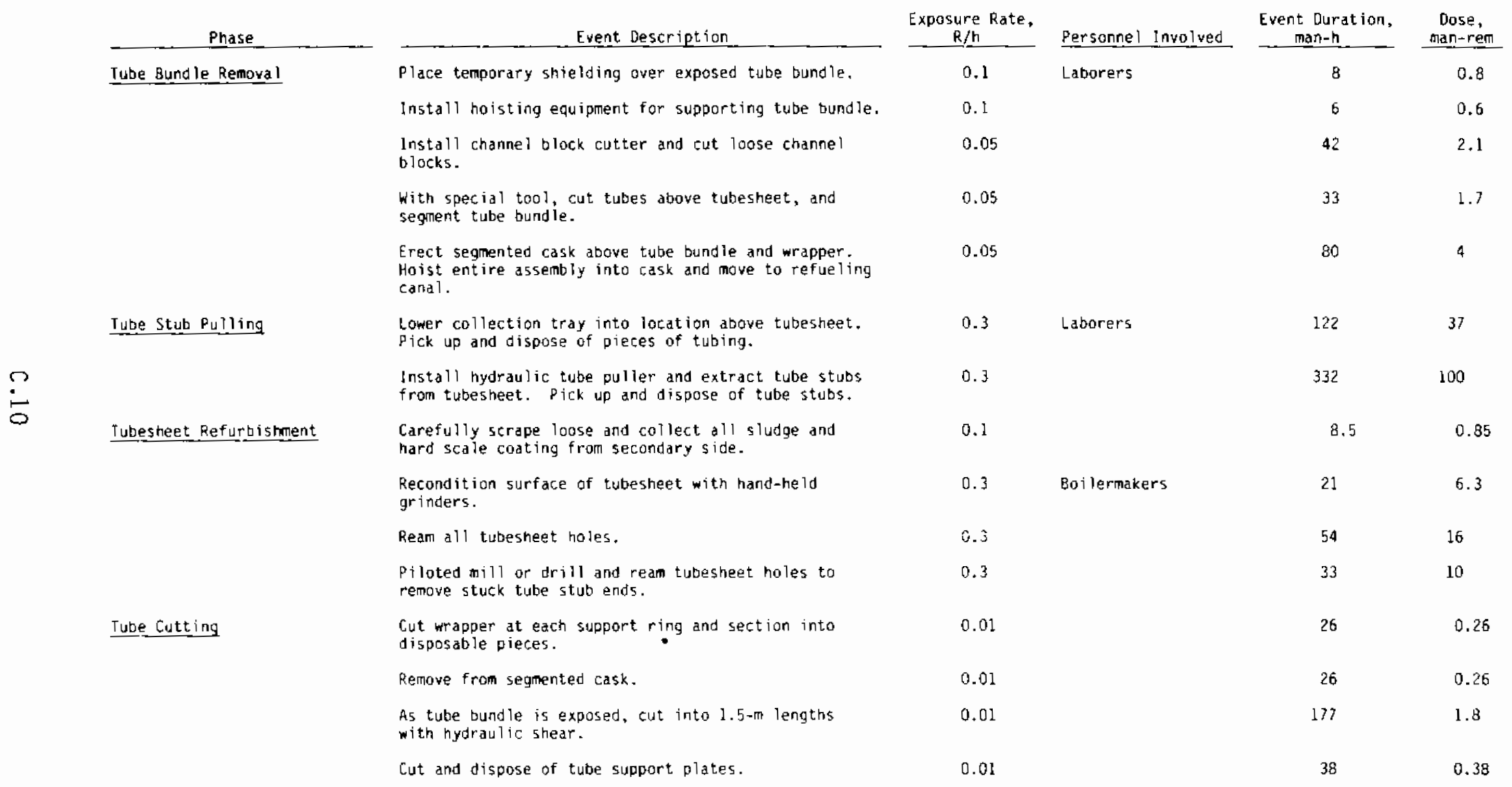




\section{TABLE C.1. (Contd)}

\begin{tabular}{|c|c|c|c|c|c|}
\hline Phase & Event Description & $\begin{array}{l}\text { Exposure Rate, } \\
R / h\end{array}$ & Personnel Involved & Event Duration, & $\begin{array}{c}\text { Dose, } \\
\text { man-rem }\end{array}$ \\
\hline \multirow[t]{11}{*}{ Steam Generator Reassembly } & Prepare access holes for final welding. & 0.3 & Boilermakers & 27 & 8.1 \\
\hline & Erect and position forged manways. & 0.3 & Boilermakers & 20 & 5 \\
\hline & We ld manways in place. & 0.3 & & 196 & 59 \\
\hline & $\begin{array}{l}\text { Remove remaining part of all channel head blocks } \\
\text { from iner wall of secondary shell. }\end{array}$ & 0.05 & & 7 & 0.35 \\
\hline & $\begin{array}{l}\text { Instail new mapper, support plate assembly, and } \\
\text { channel blocks. Correctly orient to tubesheet. }\end{array}$ & 0.05 & $\begin{array}{l}\text { Crane operator } \\
\text { Laborers }\end{array}$ & 72 & 3.6 \\
\hline & Weld channel blocks to inner surface of shell. & 0.05 & $\begin{array}{l}\text { Operators } \\
\text { Boilermakers }\end{array}$ & 62 & 3.1 \\
\hline & $\begin{array}{l}\text { Connect each } U \text {-tube to correct loading rods; pull } \\
\text { down into place evenly. }\end{array}$ & 0.05 & & 568 & 28 \\
\hline & Install antivibration bars; examine dye penetration. & 0.05 & & 16 & 0.8 \\
\hline & Expand all tubes into tubesheet. & 0.05 & & 340 & 17 \\
\hline & $\begin{array}{l}\text { Instah primary moisture separator onto arapper. } \\
\text { Weld in place. }\end{array}$ & 0.05 & & 212 & 11 \\
\hline & $\begin{array}{l}\text { Install new feedwater ring and weld to supports } \\
\text { and feedwater nozzel. }\end{array}$ & 0.01 & & 54 & 0.54 \\
\hline \multirow[t]{5}{*}{ Upper shell closure } & Prepare top of steam generator shell for welding. & 0.01 & Boilermakers & 133 & 1.3 \\
\hline & $\begin{array}{l}\text { Rig, lift, and place properly oriented upper she } 17 \\
\text { demister section. }\end{array}$ & 0.01 & Operators & 16 & 0.16 \\
\hline & weld upper steam generator shell in place. & 0.01 & Boilermakers & 2150 & 22 \\
\hline & Re-erect all other piping. & 0.01 & & 350 & 3.5 \\
\hline & Weld steam line. & 0.01 & & 192 & 1.9 \\
\hline
\end{tabular}


TABLE C.1. (Contd)

\begin{tabular}{|c|c|c|c|c|c|}
\hline Phase & Event Deseription & $\begin{array}{c}\text { Exposure Rate, } \\
\mathrm{R} / \mathrm{h}\end{array}$ & Personnel Involved & $\begin{array}{l}\text { Event Ouration, } \\
\text { man- } h\end{array}$ & $\begin{array}{l}\text { Dose, } \\
\text { man-rem }\end{array}$ \\
\hline \multirow[t]{6}{*}{ Nondestructive Examination } & $\begin{array}{l}\text { Radiographically inspect manway forging } \\
\text { installation welds. }\end{array}$ & 0.05 & & 14 & 0.7 \\
\hline & Examine dye penetration of tube-to-tubesheet welds. & 0.1 & & 29 & 2.9 \\
\hline & $\begin{array}{l}\text { Radiographically inspect wrapper-to-riser barre! } \\
\text { weld. }\end{array}$ & 0.05 & & 48 & 2.4 \\
\hline & $\begin{array}{l}\text { Radiographically inspect upper-to-lower she } 11 \\
\text { weld (from inside if possitle). }\end{array}$ & 0.05 & & 66 & 3.3 \\
\hline & Fill unit with demineralized water and pressure test. & 0.01 & $\begin{array}{l}\text { Boilermakers } \\
\text { QC inspector }\end{array}$ & 72 & 0.72 \\
\hline & $\begin{array}{l}\text { Hydrotest primary piping and secondary side of steam } \\
\text { generator. }\end{array}$ & 0.01 & $\begin{array}{l}\text { Boilermakers } \\
\text { oc inspector }\end{array}$ & 72 & 0.72 \\
\hline \multirow{2}{*}{$\begin{array}{l}\text { Postweld Heat } \\
\text { freatment }\end{array}$} & Postweld heat treat new manway installations. & 0.05 & & $i \hat{\imath}$ & 3.6 \\
\hline & $\begin{array}{l}\text { Postweld heat treat weid joining upper shell and } \\
\text { moisture separator section to lower shell. }\end{array}$ & 0.01 & & 152 & 1.5 \\
\hline Cleanup & $\begin{array}{l}\text { Remove greenhouses, staging and scaffolding, jith } \\
\text { cranes and hoists, retubing machines, welders, special } \\
\text { ventilation equipment, tooling, power and control } \\
\text { cable, and lighting. }\end{array}$ & 0.01 & & 628 & 6.3 \\
\hline TOTAL & & & & & -2300 \\
\hline
\end{tabular}




\section{REFERENCES}

1. Westinghouse Nuclear Energy Systems. Steam Generator Retubing and Refurbishment. WCAP-9398, Pittsburg, PennsyTuania.

2. Smith, R. I., G. J. Konzek and W. E. Kennedy, Jr. 1978. Technology, Safety and Costs of Decommissioning a Reference Pressurized Water Reactor Power Station. NUREG/CR-0130, Vols. I and 2 and Addendum, U.S. Nuclear Regulatory Commission, Washington, DC 20555.*

3. Rooerts, 0. R. 1960. "How to Estimate Piping Labor." The Petroleum Refiner 39(3):207-212.

4. Herkimer, H. 1958. Cost Manual for Piping and Mechanical Construction. Chemical Publishing, Inc., New York.

5. Florida Power and Light Company. 1980. Steam.Generator Repair Report Turkey Point Units 3 and 4. NRC Docket Nos. 50-250 and 50-251, Washington, D.C.

6. Kennedy, A. J. 1977. "PWR Corrosion Products: Synthes is and Significance." Babcock and Wilcox Document No. RDTPL-77-24, presented to the American Nuciear Society, November 27-December 2, 1977, San Francisco, California.

7. Ayres, J. A., ed. 1970. Decontamination of Nuclear Reactors and Equipment, Chapters $4,7,9,15,16$, and 17 . The Ronald Press Co., New York.

8. Hestinghouse Electric Corporation, R. J. Lutz, Jr., Ed. 1977. Design, Inspection, Operation and Maintenance Aspects of the WNSSS to Maintain Occupational Radiation Exposures AS LOW AS Reasonab Ty Achievable. WCAP-88-72, pittsburgh, Pennsylvania.

9. U.S. Nuclear Regulatory Commission, Dffice of Standards Development. 1979. Design, Testing and Maintenance Criteria for Normal Ventilation Exhaust Systems Air Filtration and Adsorption Units of Light-Water-Cooled Nuclear Power Plants. U.S. NRC Regulatory Guide 1.140, Rev. 1, washington, D.C.

*Avarlable for purchase from the National Technical Information Service, Springfield, VA 22161. 
NUREG/CR-1595

PNL -3454

RR

DISTRIBUTION

No of

Copies

OFF SITE

A. A. Churm

DOE Patent Division $9800 \mathrm{~S}$. Cass Avenue

Argonne, IL 60439

295 U.S. Nuclear Regulatory Commission

Division of Technical

Information and Document Control

7920 Norfolk Avenue

Bethesda, MO 20014

2 DOE Technical Information Center

R. Serbu

L.S. Nuclear Regulatory Commission

Washington, DC 20555

R. Zavadoski

Radiation Specialist

U.S. Nuclear Regulatrory Commission, Region II

Suite 3100

101 Marietta St., N.W.

Atlanta, GA 30303

D. A. Waite

Battelle Memorial Institute

$505 \mathrm{King}$ Avenue

Columbus, OH 43201
No. of

Copies

H. D. Mantz

Project Genera! Manager

Florida Power and Light Company

P. 0. Box 529100

Miami, FL 33152

H. F. Story

Corporate Health Physicist

Florida Power and Light Company

P.0. Box 529100

Miami, FL 33152

S. C. Brown

Senior Vice President

$V$ irginia Electric and Power Company

P. 0. Box 26666

Richmond, VA 23261

Henry F. Kahnhouser

Nuclear Operation Dept.

Virginia Electric and Power Company

P. 0. Box 26666

Richmond, VA 23261

H. S. Mckay

Project Engineer

Virginia Electric and Power Company

P. 0. BOX 376

Surry, VA 23883 
No. of

Copies

ONSITE

47 Pacific Northwest Laboratory

J. L. Baer

P. E. Bramson

R. A. Clark

J. R. Divine

L. G. Faust

V. F. Fitzpatrick

W. A. Glass
No. of

Copies

G. R. Hoenes (25)

W. D. McCormack

M. A. Mueller

L. D. Perrigo

G. A. Stoetze]

J. M. Taylor

E. C. Watson

W. R. Wiley

G. E. Zima

Technical Information (5)

Publishing Coordination (2) 


\section{.}




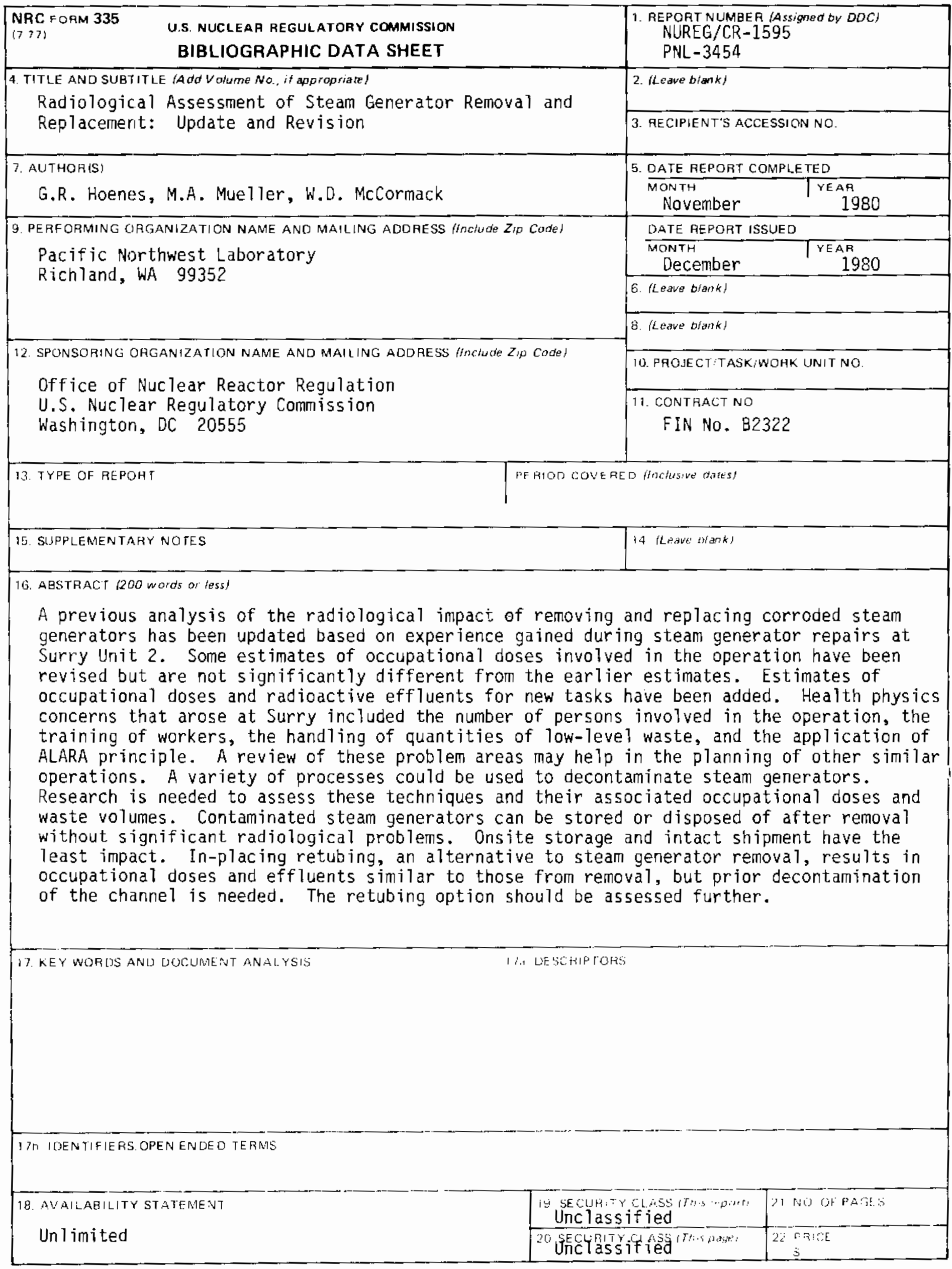


